\title{
Flexible Outsourcing and the Impacts of Labour Taxation in European Welfare States
}

\author{
ERKKI KOSKELA \\ PANU POUTVAARA
}

CESIFO WORKING PAPER NO. 2440

CATEGORY 4: LABOUR MARKETS

OCTOBER 2008

\footnotetext{
An electronic version of the paper may be downloaded

- from the SSRN website:

- from the RePEc website:

www.SSRN.com

from the CESifo website:

www.RePEc.org

www.CESifo-group.org/wp
} 


\title{
Flexible Outsourcing and the Impacts of Labour Taxation in European Welfare States
}

\begin{abstract}
In European Welfare States, low-skilled workers are typically unionized, while the wage formation of high-skilled workers is more competitive. To focus on this aspect, we analyze how flexible international outsourcing and labour taxation affect wage formation, employment and welfare in dual domestic labour markets. Higher productivity of outsourcing, lower cost of outsourcing and lower factor price of outsourcing increase wage dispersion between the high-skilled and low-skilled workers. Increasing wage tax progression of lowskilled workers decreases the wage rate and increases the labour demand of low-skilled workers. It decreases the welfare of low-skilled workers and increases both the welfare of high-skilled workers and the profit of firms.
\end{abstract}

JEL Code: E24, H22, J21, J31, J51.

Keywords: flexible outsourcing, dual labour market, impacts of labour taxation, welfare state.

Erkki Koskela Department of Economics University of Helsinki

P.O. Box 17 (Arkadiankatu7)

00014 Helsinki

Finland

erkki.koskela@helsinki.fi
Panu Poutvaara

Department of Economics

University of Helsinki

P.O. Box 17 (Arkadiankatu7)

00014 Helsinki

Finland

panu.poutvaara@helsinki.fi 


\section{Introduction}

European Welfare States are characterized by dual labour markets. Low-skilled workers are typically unionized, while high-skilled workers often negotiate on their wages individually, and, thus, face more competitive wage formation. Historically, labour unions have been able to push for relatively high wages of low-skilled workers, at the cost of a higher unemployment in Continental Europe than in the United States (see e.g. Freeman and Schettkat (2001)). During the late $20^{\text {th }}$ century and this decade, globalization has put the European welfare model under increasing pressure. Wage differences across countries constitute a central explanation for the increasing dominant business practice of international outsourcing across a wide range of industries (see e.g. Sinn (2007) for an overview and Stefanova (2006) concerning the East-West dichotomy of outsourcing). ${ }^{1}$

When outsourcing and domestic labour are substitutes, the demand for domestic homogenous labour is decreasing and its wage elasticity is increasing in the share of outsourcing (see e.g. Senses (2006) for empirical evidence). This limits the mark-up trade unions can set above the opportunity cost of labour. Outsourcing can take two alternative forms. Firms may write long-term contracts that fix the amount of outsourcing before the trade union sets the wage, i.e. strategic outsourcing, or alternatively firms may be flexible enough to decide upon the amount of outsourcing activity simultaneously with domestic labour demand after the domestic wage is set by the trade union. In the case of homogenous domestic labour the impacts of labour tax policy reforms have been analyzed in Koskela and Schöb (2008) both in the case of strategic and flexible outsourcing.

We analyze the effects of international outsourcing and wage taxation on dual domestic labour markets by assuming that the low-skilled workers are unionized, while the wages of high-skilled workers are determined competitively. ${ }^{2}$ In Koskela and

$1 \quad$ Moreover, Amiti and Wei (2005) as well as Rishi and Saxena (2004) emphasize the big difference in labour costs as the main explanation for the strong increase in outsourcing of both manufacturing and services to countries with low labour costs.

2 There are some papers that analyze the effects of outsourcing when labour is heterogeneous, like Davidson et al. (2007) and Davidson et al. (2008). However, these papers analyze labour market frictions that arise with search, while we focus on the role of labour unions. Importantly, the 
Poutvaara (2008) we have assumed that outsourcing in this kind of dual domestic labour markets is strategic, but now we study how flexible outsourcing and labour taxation affect wage formation, employment and welfare in dual domestic labour markets. We use a production function where outsourcing is complementary for domestic high-skilled labour and substitutable to domestic low-skilled labour.

We show that in the presence of flexible outsourcing the own wage elasticity and the cross wage elasticity for the low-skilled labour demand depend negatively on the cost of outsourcing, and on the factor price of outsourcing and positively on the payroll tax, and the own wage elasticity and the cross wage elasticity for the highskilled labour demand are independent of the cost of outsourcing and the payroll tax. We also find that the outsourcing elasticities are constant with respect to the low-skilled wage, the payroll tax, the productivity of outsourcing and the cost of outsourcing. When the high-skilled wage adjusts to equalize labour demand and labour supply, the high-skilled wage depends negatively on the low-skilled wage and the payroll tax. The high-skilled wage is independent of the high-skilled wage tax parameters in the case of high-skilled workers' Cobb-Douglas utility function. Moreover, the high-skilled wage depends on the cost of outsourcing and of the productivity of outsourced production indirectly, through its effect on low-skilled wage. The reason for this is that high-skilled and low-skilled labour are complements, so that low-skilled wage affects how much low-skilled labour input firms want to employ. However, there is no direct link from outsourcing cost and outsourcing productivity parameters to high-skilled wage.

In the presence of flexible outsourcing the lower cost of outsourcing, the lower factor price of outsourcing and the higher productivity of outsourced production will decrease the wage for the low-skilled labour and increase the wage for the high-skilled labour, thereby inducing higher wage dispersion. The higher low-skilled wage tax rate will increase the wage for the low-skilled labour and decrease the wage for high-skilled labour and the higher low-skilled wage tax exemption will decrease the wage for the low-skilled labour and will increase the wage for the high-skilled labour. Similar

effects of labour taxation may differ even qualitatively between models with labour unions and with search related employment (see e.g. Pissarides (1998) concerning the analysis of this issue in the absence of outsourcing). 
qualitative effects arise in the absence of outsourcing. With flexible outsourcing, the higher payroll tax for the firms will decrease the wage for the low-skilled and highskilled labour. In the absence of outsourcing, the higher payroll tax for the firms will decrease the wage for the high-skilled labour, but has no effect on the wage of lowskilled labour.

Increasing the wage tax and the tax exemption for the low-skilled workers to keep the relative burden per worker constant implies a higher degree of tax progression. This will decrease the wage rate and increase labour demand of low-skilled workers, while it will have no effect on the labour demand of high-skilled workers. Corresponding effects arise in the absence of outsourcing. We show that a higher degree of tax progression for low-skilled workers will decrease the welfare of lowskilled workers and increase the welfare of high-skilled workers. Also the profits of firms increase.

We proceed as follows: Section II presents the time sequence of the decisions regarding some policy issues associated with labour taxes, wage setting for domestic low-skilled workers, labour demand for domestic high-skilled and low skilled workers, outsourcing and wage setting for high-skilled workers. We study the segmented domestic labour demand for heterogenous work force and outsourcing decision and wage formation of high-skilled workers due to market equilibrium under labour taxation in section III. Wage formation by the monopoly labour union for low-skilled workers under a linearly progressive wage tax levied on workers and a proportional payroll tax levied on firms is analyzed in section IV. In section V we study the impacts of low-skilled wage progression on employment, welfare and profits. Finally, we summarize conclusions in section VI.

\section{Basic Framework}

We analyze a model with heterogeneous domestic workers and international outsourcing. The production combines labour services by high-skilled workers and lowskilled workers. Low-skilled labour services can be provided either by the firm's own workers, or obtained from abroad through international outsourcing. We assume that 
the firms may be flexible enough to decide upon the amount of outsourcing activity only after the wage is set by the trade union. The time sequence for this case is described by Figure 1 .

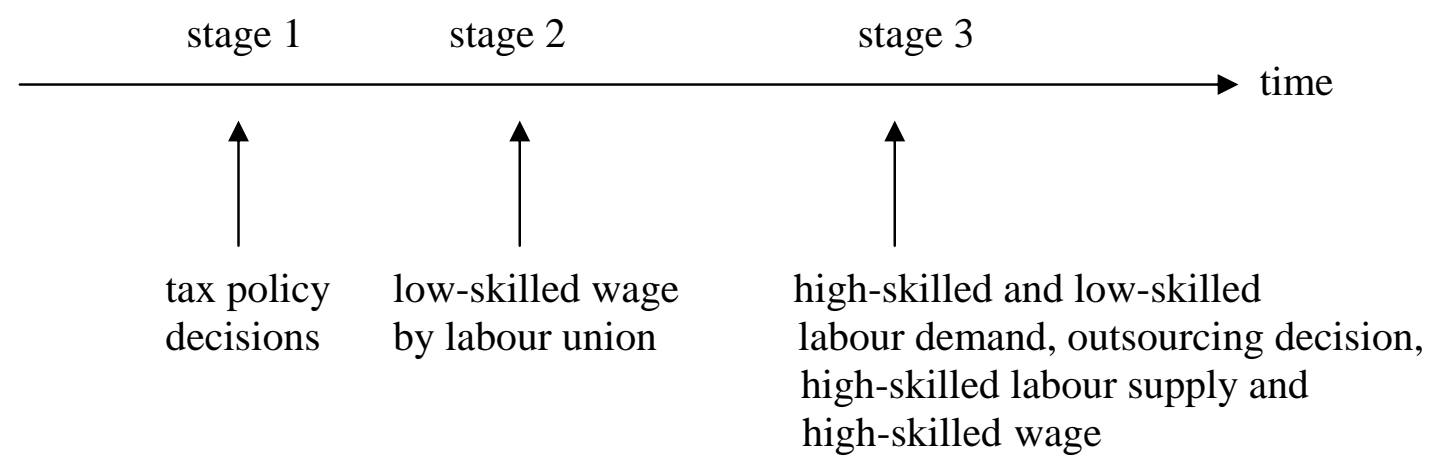

Figure 1: Time sequence of decisions

The government sets its policy at stage 1 . At stage 2 conditional on policy choices by the government, the labour union determines the wage for the low-skilled workers by taking into account how this affects the demand for labour and outsourcing by the firms. We assume that there are many industries, so that each labour union represents only a small fraction of the total labor force. At stage 3, firms decide on domestic employment and international outsourcing. The wages of the high-skilled labour adjust to equalize labour demand and labour supply. The decisions at each stage are analyzed by using backward induction. 


\section{Labour Demand, Outsourcing Decisions and High-Skilled Wage Formation}

\section{III.1. Labour Demand and Outsourcing}

At the last stage, the firm decides on the high-skilled labour demand $H$, the low-skilled labour demand $L$ and outsourcing $M$ in order to maximize the profit function

$$
\underbrace{\operatorname{Max}}_{(H, L, M)} \pi=F(H, L, M)-\widetilde{w}_{H} H-\widetilde{w}_{L} L-w_{M} M-g(M)
$$

When deciding on its labour demand and outsourcing, each firm takes as given the gross wage for high-skilled labour, $\widetilde{w}_{H}=w_{H}(1+s)$, and the gross wage for low-skilled labour, $\tilde{w}_{L}=w_{L}(1+s)$, where $s$ is the proportional payroll tax levied on the firm. In order to obtain $M$ units of outsourced low-skilled labour input, we assume that firms acquire the low-skilled labour input at the factor price $w_{M}$ and also firms have to spend $g(M)=0,5 c M^{2}$ with $g^{\prime}(M)=c M>0$ and $g^{\prime \prime}(M)=c>0$ to establish the capacity for foreign outsourcing concerning the network of suppliers in the relevant low-wage countries.

We follow Koskela and Stenbacka (2007) by assuming a general and reasonable Cobb-Douglas-type production function with decreasing returns to scale according to

three labour inputs, i.e. $F(H, L, M)=\left[H^{a}(L+\gamma M)^{1-a}\right]^{\rho}$, where the parameters $\rho$ and $a$ are assumed to satisfy the following assumptions : $0<\rho<1$ and $0<a<1$. The parameter $\gamma>0$ captures the productivity of the outsourced low-skilled labour input relative to the domestic low-skilled labour input. The marginal products of high-skilled labour, low-skilled labour and outsourcing are: $F_{H}=\rho Y^{\rho-1} a H^{a-1}(L+\gamma M)^{1-a}$, 
$F_{L}=\rho Y^{\rho-1} H^{a}(1-a)(L+\gamma M)^{-a}, \quad$ and $\quad F_{M}=\gamma \rho Y^{\rho-1} H^{a}(1-a)(L+\gamma M)^{-a}=\gamma F_{L}$

respectively, where $Y=H^{a}(L+\gamma M)^{1-a}$. The outsourced low-skilled labour input affects the marginal products of the domestic high-skilled and low-skilled labour inputs as follows:

$$
\begin{aligned}
F_{H M} & =\rho^{2} Y^{\rho-1} a H^{a-1}(1-a) \gamma(L+\gamma M)^{-a}>0 \\
F_{L M} & =-\rho Y^{\rho-1} H^{a}(1-a) \gamma(L+\gamma M)^{-a-1}[1-\rho(1-a)]<0 .
\end{aligned}
$$

For this production function the domestic high-skilled labour input and the outsourced low-skilled labour input are complements, whereas the low-skilled domestic labour input and the outsourced low-skilled labour input are substitutes in terms of the marginal product effects of outsourcing. Also one can calculate from the production function that the domestic high-skilled and low-skilled labour are complements, i.e. $F_{H L}>0$. Given the wages, the outsourcing cost function and the tax parameters the first-order conditions characterizing the domestic high-skilled and low-skilled labour demands and outsourcing are

$$
\begin{aligned}
& \pi_{H}=\rho\left[H^{a}(L+\gamma M)^{1-a}\right]^{\rho-1} a H^{a-1}(L+\gamma M)^{1-a}-\widetilde{w}_{H}=0 \\
& \pi_{L}=\rho\left[H^{a}(L+\lambda M)^{1-a}\right]^{\rho-1}(1-a) H^{a}(L+\gamma M)^{-a}-\widetilde{w}_{L}=0 \\
& \pi_{M}=\rho\left[H^{a}(L+\lambda M)^{1-a}\right]^{\rho-1} \gamma(1-a) H^{a}(L+\gamma M)^{-a}-w_{M}-c M=0 .
\end{aligned}
$$

These first-order conditions imply the following relationship between the high-skilled labour ( $H$ ) and the low-skilled labour inclusive of outsourcing $(L+\gamma M)$

$$
H=\frac{w_{L}}{w_{H}} \frac{a}{1-a}(L+\gamma M) .
$$

Using (3b) and (3c) we have 


$$
M^{*}=\frac{\left(\gamma w_{L}(1+s)-w_{M}\right)}{C}
$$

where $\frac{M_{w_{L}}^{*} w_{L}}{M^{*}}=\frac{M_{s}^{*}(1+s)}{M^{*}}=\frac{M_{\gamma}^{*} \gamma}{M^{*}}=\frac{\gamma w_{L}(1+s)}{\gamma w_{L}(1+s)-w_{M}}=1+\frac{w_{M}}{c M^{*}}>1, \quad-\frac{M_{c}^{*} c}{M^{*}}=1 \quad$ and $-\frac{M_{w_{M}}^{*} w_{M}}{M^{*}}=\frac{w_{M}}{2 w_{L}(1+s)-w_{M}}=\frac{w_{M}}{c M^{*}}>0 \quad$ so that $\quad-\left(\frac{M_{c}^{*} c}{M^{*}}+\frac{M_{w_{M}}^{*} w_{M}}{M^{*}}\right)=1+\frac{w_{M}}{c M^{*}}>1$.

According to (5) optimal flexible outsourcing requires that $\gamma w_{L}(1+s)>w_{M}$ so that factor price of outsourcing should be smaller than the gross factor price of domestic low-skilled labour multiplied by the relative productivity of outsourcing. Higher lowskilled domestic wage rate, higher payroll tax and higher productivity of outsourced labour input, lower outsourcing cost and lower factor price of outsourcing will increase outsourcing.

Substituting the RHS of (4) into (3b) gives (see Appendix A) the low-skilled labour demand, which can be expressed as follows

$$
L^{*}=m w_{L}^{-\varepsilon_{L}^{L}} w_{H}^{-\varepsilon_{H}^{L}}(1+s)^{-\varepsilon}-\gamma M^{*}=m w_{L}^{-\varepsilon_{L}^{L}} w_{H}^{-\varepsilon_{H}^{L}}(1+s)^{-\varepsilon}-\gamma\left(\frac{\gamma w_{L}(1+s)-w_{M}}{c}\right),
$$

where $m=\left[\rho a^{a \rho}(1-a)^{1-a \rho}\right] \frac{1}{1-\rho}>0, \varepsilon_{L}^{L}=\frac{1-\rho a}{1-\rho}>1$ and $\varepsilon_{H}^{L}=\frac{\rho a}{1-\rho}>0$, which are the own wage elasticity and the cross wage elasticity of the low-skilled labour in the absence of outsourcing . ${ }^{3}$ These are higher with weaker decreasing returns to scale. In the absence of outsourcing the payroll tax elasticity of the low-skilled labour is $\varepsilon=-\frac{L_{s}(1+s)}{L}=\frac{1}{1-\rho}>1$ because of the decreasing returns to scale. According to (6), a more extensive outsourcing activity will decrease the low-skilled labour demand. This

In the presence of perfect substitutability between two types of labour inputs, i.e. between $L$ and $M$, we would have $\gamma=1$. However, qualitative results would be similar. 
feature is consistent with empirical evidence. ${ }^{4}$ In the presence of outsourcing the wage elasticities of the low-skilled labour, $-\left.\frac{L_{w_{L}}^{*} w_{L}}{L^{*}}\right|_{M>0}$ and $-\left.\frac{L_{w_{H}}^{*} w_{H}}{L^{*}}\right|_{M>0}$, can be written as follows

$$
\begin{gathered}
\eta_{L}^{f}=\varepsilon_{L}^{L}\left(1+\gamma \frac{M^{*}}{L^{*}}\right)+\gamma \frac{M^{*}}{L^{*}}+\gamma \frac{w_{M}}{c L^{*}}=\varepsilon_{L}^{L}+\frac{\gamma}{L^{*}}\left(\left(1+\varepsilon_{L}^{L}\right) M^{*}+\frac{w_{M}}{c}\right) \\
\eta_{H}^{f}=\varepsilon_{H}^{L}\left(1+\gamma \frac{M^{*}}{L^{*}}\right) .
\end{gathered}
$$

Concerning these wage elasticities we find that $\frac{\partial \eta_{L}^{f}}{\partial M^{*}}=\frac{\gamma}{L^{*}}\left(1+\varepsilon_{L}^{L}\right)-\frac{\gamma_{M}^{*}}{L^{* 2}}\left(\left(1+\varepsilon_{L}^{L}\right) M^{*}+\frac{w_{M}}{c}\right)=\frac{\gamma}{L^{*}}\left(\left(1+\varepsilon_{L}^{L}\right)+\frac{\gamma}{L^{*}}\left(1+\varepsilon_{L}^{L}\right) M^{*}+\frac{\gamma}{L^{*}} \frac{w_{M}}{C}\right)>0$ and $\frac{\partial \eta_{H}^{f}}{\partial M^{*}}=\varepsilon_{H}^{L} \gamma\left[\frac{L^{*}-M^{*} L_{M}^{*}}{L^{* 2}}\right]=\varepsilon_{H}^{L} \frac{\gamma}{L^{*}}\left(1+\gamma \frac{M^{*}}{L^{*}}\right)>0$ so that when outsourcing will change, the own wage and cross wage elasticities of the low-skilled labour demand increase. These are in conformity with empirical evidence. ${ }^{5}$ Differentiating (7a) with respect to $s$ gives

$$
\frac{\partial \eta_{L}^{f}}{\partial s}=\left(1+\varepsilon_{L}^{L}\right) \gamma\left[\frac{\left(L^{*} M_{s}^{*}-M^{*} L_{s}^{*}\right)}{L^{* 2}}\right]+\frac{\gamma w_{M}}{c}\left(-\frac{L_{s}^{*}}{L^{* 2}}\right)>0
$$

so that the payroll tax in the presence of outsourcing will have a positive effect on the wage elasticity of the low-skilled labour demand. Comparative statics is qualitatively similar in terms of $\eta_{H}^{f}$, but there is no wage elasticity effect of payroll tax in the

$4 \quad$ For instance Diehl (1999) has presented empirical evidence from German manufacturing industries in support of this hypothesis. Moreover, Görg and Hanley (2005) have used plant-level data of the Irish electronic sector to empirically conclude that international outsourcing reduces plant-level labour demand.

$5 \quad$ Senses (2006) has provided empirical evidence according to which a production mode with more ttoutsourcing seems to increase the wage elasticity of labour demand. Also Slaughter (2001) and Hasan et al. (2007) have shown that international trade has increased the wage elasticity of labour demand. 
absence of outsourcing, i.e. $\left.\frac{\partial \eta_{L}^{f}}{\partial s}\right|_{M=0}=0$. In the presence of flexible outsourcing the payroll tax elasticity of the low-skilled labour, $-\left.\frac{L_{s}^{*}(1+s)}{L^{*}}\right|_{M>0}$, is

$$
\eta_{s}^{f}=\varepsilon\left(1+\gamma \frac{M^{*}}{L^{*}}\right)+\gamma \frac{M^{*}}{L^{*}} \frac{M_{s}^{*}(1+s)}{M^{*}}=\varepsilon\left(1+\gamma \frac{M^{*}}{L^{*}}\right)+\gamma \frac{M^{*}}{L^{*}}\left(1+\frac{w_{M}}{c M^{*}}\right)>0
$$

so that higher outsourcing raises this elasticity as well. The effect of outsourcing cost on the wage elasticity of low-skilled labour is

$$
\begin{aligned}
\frac{\partial \eta_{L}^{f}}{\partial c} & =\left(1+\varepsilon_{L}^{L}\right) \gamma\left[\frac{\left(L^{*} M_{c}^{*}-M L_{c}^{*}\right)}{L^{* 2}}\right]-\frac{\gamma w_{M}}{\left(c L^{*}\right)^{2}}\left(L^{*}+c L_{c}^{*}\right) \\
& =-\frac{\left(1+\varepsilon_{L}^{L}\right) \gamma M^{*}}{c L^{*}}\left(1+\gamma \frac{M^{*}}{L^{*}}\right)-\frac{\gamma w_{M}}{c^{2} L^{*}}\left(1+\gamma \frac{M^{*}}{L^{*}}\right)=-\frac{\gamma}{c L^{*}}\left(\left(1+\varepsilon_{L}^{L}\right) M^{*}+\frac{w_{M}}{c}\right)\left(1+\gamma \frac{M^{*}}{L^{*}}\right)<0
\end{aligned}
$$

so that lower outsourcing cost will increase wage elasticity of domestic low-skilled labour demand. Also one can show that higher outsourcing productivity will increase the wage elasticity, i.e. $\frac{\partial \eta_{L}^{f}}{\partial \gamma}>0$. The effect of factor price of outsourcing on the wage elasticity of low-skilled labour is 


$$
\begin{aligned}
& \frac{\partial \eta_{L}^{f}}{\partial w_{M}}=\left(1+\varepsilon_{L}^{L}\right) \gamma\left[\frac{\left(L^{*} M_{w_{M}}^{*}-M L_{w_{M}}^{*}\right)}{L^{* 2}}\right]+\frac{\gamma}{c}\left[\frac{L^{*}-w_{M} L_{w_{M}}^{*}}{L^{* 2}}\right] \\
& =\frac{\left(1+\varepsilon_{L}^{L}\right) \gamma M^{*}}{w_{M} L^{*}}\left(\frac{M_{w_{M}}^{*} w_{M}}{M^{*}}-\frac{L_{w_{M}}^{*} w_{M}}{L^{*}}\right)+\frac{\gamma}{c L^{*}}\left(1-\frac{L_{w_{M}}^{*} w_{M}}{L^{*}}\right)
\end{aligned}
$$

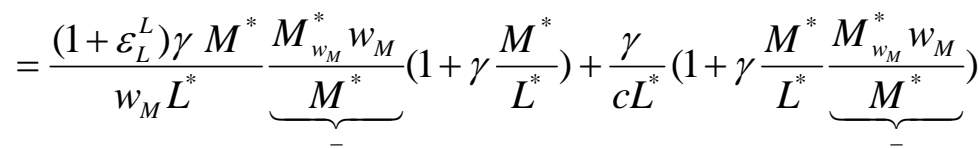

$$
\begin{aligned}
& =-\frac{\gamma}{c L^{*}}\left[\varepsilon_{L}^{L}+\gamma \frac{M^{*}}{L^{*}}\left(\left(1+\varepsilon_{L}^{L}\right) \gamma+\frac{w_{M}}{c M^{*}}\right)\right]<0 .
\end{aligned}
$$

Of course, lower factor price of outsourcing will increase the wage elasticity of domestic low-skilled labour demand.

Finally, substituting the RHS of equation (6) into the relationship in equation (4) gives the following demand for the high-skilled labour

$$
H^{*}=\frac{m a}{1-a} w_{H}^{-\varepsilon_{H}^{H}} w_{L}^{-\varepsilon_{L}^{H}}(1+s)^{-\varepsilon},
$$

where $\varepsilon_{H}^{H}=-\frac{H_{w_{H}}^{*} w_{H}}{H^{*}}=\frac{1-\rho(1-a)}{1-\rho}>1, \varepsilon_{L}^{H}=-\frac{H_{w_{L}}^{*} w_{L}}{H^{*}}=\frac{\rho(1-a)}{1-\rho}>0$ and $\varepsilon=-\frac{H_{s}^{*}(1+s)}{H^{*}}=\frac{1}{1-\rho}>1$. These elasticities are also higher with weaker decreasing returns to scale, but unlike in the case with the low-skilled labour, both the own wage and cross wage labor demand elasticities, and the payroll tax elasticity for the highskilled labour are independent of outsourcing. The higher own wage, cross wage and payroll tax will of course affect negatively the high-skilled labour demand.

We can now summarize our findings regarding the properties of the domestic labour demand as follows.

Proposition 1 In the presence of flexible outsourcing 
(a) both the own wage and the cross wage elasticities for the low-skilled labour demand depend negatively on the cost of outsourcing and factor price of outsourcing, and positively on the payroll tax, and

(b) both the own wage and the cross wage elasticities for the high-skilled labour demand are independent of the cost of outsourcing and the payroll $\operatorname{tax}$.

Proposition 1 reveals an asymmetry in how the demand for high-skilled and low-skilled labor react to the cost of outsourcing and the level of payroll taxes. An increase in outsourcing cost or payroll tax would increase the own wage elasticity, and the cross wage elasticity for the low-skilled labour demand, while having no effect on the elasticities for the high-skilled labour demand.

\section{III.2. Wage Formation for High-Skilled Workers}

\section{III.2.1 Optimal Labour Supply of High-Skilled Workers}

We assume that the market equilibrium for the high-skilled wage $w_{H}$ follows from the equality of labour demand and the labour supply by using the case of CobbDouglas (C-D) utility function, so that the elasticity of substitution between consumption and leisure is one. First we derive labour supply and after that the wage formation from market equilibrium by taking the low-skilled wage $w_{L}$ as given.

We assume that the government can employ the proportional wage tax $t_{H}$ for high-skilled worker, which is levied on the wage rate $w_{H}$ minus tax exemption $e_{H}$. Thus the total tax base in this case is $\left(w_{H}-e_{H}\right) H$, where $H$ is labour supply. In the presence of positive tax exemption the marginal wage tax exceeds the average wage tax rate $t_{H}\left(1-e_{H} / w_{H}\right)$ so that the system is linearly progressive. ${ }^{6}$ The net-of-tax wage, the high-skilled worker receives, is $\hat{w}_{H}=\left(1-t_{H}\right) w_{H}+t_{H} e_{H}$.

For a seminal paper about tax progression, see Musgrave and Thin (1948), and for another elaboration, see e.g. Lambert (2001, chapters 7-8). 
Labour supply of the high-skilled worker is determined by utility maximization. In the case of the C-D utility function maximizing $U(C, H)=C^{\mu}(1-H)^{1-\mu}, 0<\mu<1$, s.t. $\hat{w}_{H} H=C$ with respect to labour supply $H$ gives $U_{H}=\mu\left(\hat{w}_{H} H\right)^{\mu-1}(1-H)^{1-\mu} \hat{w}_{H}-(1-\mu)\left(\hat{w}_{H} H\right)^{\mu}(1-H)^{-\mu}=0$ so that

$$
H^{s}=\mu
$$

Therefore under this assumption the net-of-tax wage $\hat{w}_{H}=\left(1-t_{H}\right) w_{H}+t_{H} e_{H}$ will have no effect on labour supply when the substitution and income effects of wage rate cancel each other. It is important to emphasize that a central finding in the empirical labour market literature is that labour supply tends to be quite unresponsive along the intensive margin (see for empirical evidence, e.g. Immervoll et al (2007) and Blundell and MaCurdy (1999)). Therefore, we focus on this finding concerning the market equilibrium of high-skilled workers.

\section{III.2.2 Market Equilibrium for High-Skilled Wage Formation}

Unlike in the case of low-skilled workers we assume that the high-skilled wage $w_{H}$ is determined by the market equilibrium concerning the equality of the labour demand function and the labour supply function. In the case of C-D utility function the equality $H^{*}=H^{s}$ gives $\frac{m a}{1-a} w_{H}^{-\varepsilon_{H}^{H}} w_{L}^{-\varepsilon_{L}^{H}}(1+s)^{-\varepsilon}=\mu$, which allows to solve

$$
w_{H}=\left[\frac{\mu(1-a)}{m a}\right]^{-\frac{1}{\varepsilon_{H}^{H}}} w_{L}^{-\frac{\varepsilon_{L}^{H}}{\varepsilon_{H}^{H}}}(1+s)^{-\frac{\varepsilon}{\varepsilon_{H}^{H}}}
$$

where $\varepsilon_{L}^{H} / \varepsilon_{H}^{H}=\frac{\rho(1-a)}{1-\rho(1-a)}>0$ and $\varepsilon / \varepsilon_{H}^{H}=\frac{1}{1-\rho(1-a)}>1$. The comparative statics in terms of $w_{L}$ is 


$$
\frac{\partial w_{H}}{\partial w_{L}}=-\frac{\varepsilon_{L}^{H}}{\varepsilon_{H}^{H}}\left[\frac{\mu(1-a)}{m a}\right]^{-\frac{1}{\varepsilon_{H}^{H}}} w_{L}^{-\frac{\varepsilon_{L}^{H}}{\varepsilon_{H}^{H}}}(1+s)^{-\frac{\varepsilon}{\varepsilon_{H}^{H}}}=-\frac{\varepsilon_{L}^{H}}{\varepsilon_{H}^{H}} \frac{w_{H}}{w_{L}}<0
$$

Equation (15) lies in conformity with empirics concerning the negative relationship between high-skilled and low-skilled wages. ${ }^{7}$ The effect of payroll tax on the wage rate of high-skilled workers is

$$
\frac{\partial w_{H}}{\partial s}=-\frac{\varepsilon}{\varepsilon_{H}^{H}}\left[\frac{\mu(1-a)}{m a}\right]^{-\frac{1}{\varepsilon_{H}^{H}}} w_{L}^{-\frac{\varepsilon_{L}^{H}}{\varepsilon_{H}^{H}}}(1+s)^{-\frac{\varepsilon}{\varepsilon_{H}^{H}}-1}=-\frac{\varepsilon}{\varepsilon_{H}^{H}} \frac{w_{H}}{1+s}<0
$$

so that higher payroll tax will decrease the wage rate of high-skilled workers because it decreases labour demand given the labour supply (concerning empirical evidence, see. e.g. Daveri and Tabellini (2000), and Bingley and Lanot (2002)). According to (13) the high-skilled wage rate does not depend on the outsourcing cost and the productivity of outsourcing.

We can now summarize our findings regarding the properties of the high-skilled wage determination in the presence of outsourcing as follows.

Proposition 2 In the presence of flexible outsourcing

(a) the high-skilled wage depends negatively on the low-skilled wage and the payroll tax, but is independent of the high-skilled wage tax parameters in the case of high-skilled workers' Cobb-Douglas utility function, and

(b) the high-skilled wage is also directly independent of the cost of outsourcing and the productivity of outsourcing, but depends indirectly on the low-skilled wage change and the productivity of the low-skilled wage change so that higher outsourcing cost will decrease, while higher productivity of low-skilled labour input relative to the domestic labour input will increase the high-skilled wage.

See evidence from various countries which lies in conformity with this, e.g. Braun and Scheffel (2007), Feenstra and Hanson (1999, 2001), Hijzen et al (2005), Hijzen (2007), Egger and Egger (2006), Munch and Skaksen (2005), Riley and Young (2007) and Geishecker and Görg (2008). 
In the first sight, it may appear surprising that the high-skilled wage reacts negatively to the low-skilled wage tax, but is independent of their own wage tax. The intuition for this relies on our assumption that the high-skilled workers have a Cobb-Douglas utility function. With it, income and substitution effects of a tax increase on the labor supply cancel each other out.

\section{Wage Formation by Monopoly Labour Union}

Now we analyze the wage formation of low-skilled workers so that it takes place in anticipation of optimal labour and outsourcing decisions by the firm. We analyze the wage formation by the monopoly union (see also Cahuc and Zylberberg (2004), p. 401-403 concerning the monopoly union specification), which determines the wage for low-skilled workers in anticipation of optimal in-house low-skilled labour demand in the presence of flexible outsourcing determined simultaneously and of market equilibrium for the high-skilled wage $w_{H} \cdot{ }^{8}$

\section{IV.1. Wage Formation by the Monopoly Labour Union}

We investigate the wage formation by monopoly labour union when there is proportional payroll tax, and the linearly progressive wage tax for low-skilled workers. The market equilibrium for the high-skilled wage $w_{H}$ follows from the equality of labour demand and the labour supply by focusing the case of C-D utility function. The monopoly labour union determines the wage for low-skilled workers in anticipation of optimal domestic labour demand and outsourcing decisions by the firm. We assume that government can employ a proportional tax rate $t_{L}$, which is levied on the wage rate $w_{L}$ minus a tax exemption $e$, i.e. the total tax base is $\left(w_{L}-e\right) L^{*}$. In the presence of a positive tax exemption the marginal wage tax exceeds the average wage tax rate

8 In Western European countries, which we like to focus, labour market institutions are close to this (see e.g. Freeman (2008)). 
$t_{L}\left(1-e / w_{L}\right)$ so that the system is linearly progressive and the net-of-tax wage is $\hat{w}_{L}=\left(1-t_{L}\right) w_{L}+t_{L} e$.

The objective function of the labour union is assumed to be $V=\left(\left(1-t_{L}\right) w_{L}+t_{L} e-b_{L}\right) L^{*}+b_{L} N=\left(\hat{w}_{L}-b_{L}\right) L^{*}+b_{L} N$, where $b_{L}$ is the (exogenous) outside option available to the low-skilled workers and $N$ is the number of labour union members. The monopoly labour union sets wage for the low-skilled workers so as to maximize the surplus according to

$$
\underbrace{\max }_{\left(w_{L}\right)} V=\left(\hat{w}_{L}-b_{L}\right) L^{*}+b_{L} N
$$

s.t. $\quad L^{*}=m w_{L}^{-\varepsilon_{L}^{L}} w_{H}^{-\varepsilon_{H}^{L}}(1+s)^{-\varepsilon}-\gamma M^{*}=m w_{L}^{-\varepsilon_{L}^{L}} w_{H}^{-\varepsilon_{H}^{L}}(1+s)^{-\varepsilon}-\gamma\left(\frac{\gamma w_{L}(1+s)-w_{M}}{c}\right) \quad$ and $H^{*}=H^{s}$

where in the presence of payroll tax $H^{*}=\frac{m a}{1-a} w_{H}^{-\varepsilon_{H}^{H}} w_{L}^{-\varepsilon_{L}^{H}}(1+s)^{-\varepsilon}$ and $H^{s}=\mu$, which implies $w_{H}=\left[\frac{\mu(1-a)}{m a}\right]^{-\frac{1}{\varepsilon_{H}^{H}}} w_{L}^{-\frac{\varepsilon_{L}^{H}}{\varepsilon_{H}^{H}}}(1+s)^{-\frac{\varepsilon}{\varepsilon_{H}^{H}}}$ (see equations (12), (13) and (14)).

The first-order condition associated with (17) is

$V_{w_{L}}=\frac{L^{*}}{w_{L}}\left[\left(1-t_{L}\right) w_{L}+\left(\left(1-t_{L}\right) w_{L}+t_{L} e-b_{L}\right)\left(\frac{L_{w_{L}}^{*} w_{L}}{L^{*}}+\frac{L_{w_{H}}^{*} w_{H}}{L^{*}} \frac{\partial w_{H}}{\partial w_{L}} \frac{w_{L}}{w_{H}}\right)\right]=0$.

and this can be written as follows

$\left.V_{w_{L}}=\left(1-t_{L}\right) w_{L}\left(1-\left(\eta_{L}^{f}+\eta_{H}^{f} \frac{\partial w_{H}}{\partial w_{L}} \frac{w_{L}}{w_{H}}\right)\right)+\left(b_{L}-t_{L} e\right)\left(\eta_{L}^{f}+\eta_{H}^{f} \frac{\partial w_{H}}{\partial w_{L}} \frac{w_{L}}{w_{H}}\right)\right)=0$ 
where $\frac{\partial w_{H}}{\partial w_{L}} \frac{w_{L}}{w_{H}}=-\frac{\varepsilon_{L}^{H}}{\varepsilon_{H}^{H}}$, the own wage elasticity of low-skilled labour demand is $\eta_{L}^{f}=\varepsilon_{L}^{L}\left(1+\gamma \frac{M^{*}}{L^{*}}\right)+\gamma \frac{M^{*}}{L^{*}}+\gamma \frac{w_{M}}{c L^{*}}=\varepsilon_{L}^{L}+\frac{\gamma}{L^{*}}\left(\left(1+\varepsilon_{L}^{L}\right) M^{*}+\frac{w_{M}}{c}\right)$ and the cross wage elasticity of low-skilled labour demand $\eta_{H}^{f}=\varepsilon_{H}^{L}\left(1+\gamma \frac{M^{*}}{L^{*}}\right)$. These low-skilled labour demand elasticities are not constant because the low-skilled labour demand, $L^{*}=m w_{L}^{-\varepsilon_{L}^{L}} w_{H}^{-\varepsilon_{H}^{L}}(1+s)^{-\varepsilon}-\gamma\left(\frac{\gamma w_{L}(1+s)-w_{M}}{c}\right) L^{*}=m w_{L}^{-\varepsilon_{L}^{L}} w_{H}^{-\varepsilon_{H}^{L}}(1+s)^{-\varepsilon}-\gamma^{2} \frac{w_{L}(1+s)}{c}$

depends negatively on the following variables: the high-skilled wage, the low-skilled wage, the productivity of the outsourced low-skilled labour input relative to the domestic low-skilled labour input, and the payroll tax and positively on the cost of outsourcing and the factor price of outsourcing.

Equation (19) can be expressed as follows

$$
\begin{aligned}
w_{L}^{*} & =\left(\frac{\eta_{L}^{f}-\eta_{H}^{f} \frac{\varepsilon_{L}^{H}}{\varepsilon_{H}^{H}}}{\eta_{L}^{f}-\eta_{H}^{f} \frac{\varepsilon_{L}^{H}}{\varepsilon_{H}^{H}}-1}\right) \hat{b}_{L}=\left(\frac{\gamma\left(\frac{M^{*}}{L^{*}}+\frac{w_{M}}{c L^{*}}\right)+\left(\varepsilon_{L}^{L}-\varepsilon_{H}^{L} \frac{\varepsilon_{L}^{H}}{\varepsilon_{H}^{H}}\right)\left(1+\gamma \frac{M^{*}}{L^{*}}\right)}{\gamma\left(\frac{M^{*}}{L^{*}}+\frac{w_{M}}{c L^{*}}\right)+\left(\varepsilon_{L}^{L}-\varepsilon_{H}^{L} \frac{\varepsilon_{L}^{H}}{\varepsilon_{H}^{H}}\right)\left(1+\gamma \frac{M^{*}}{L^{*}}\right)-1}\right) \hat{b}_{L} \\
& =\left(\frac{\left(\varepsilon_{L}^{L}-\varepsilon_{H}^{L} \frac{\varepsilon_{L}^{H}}{\varepsilon_{H}^{H}}\right)+\left(1+\varepsilon_{L}^{L}-\varepsilon_{H}^{L} \frac{\varepsilon_{L}^{H}}{\varepsilon_{H}^{H}}\right) \gamma \frac{M^{*}}{L^{*}}+\gamma \frac{w_{M}}{c L^{*}}}{\left(\varepsilon_{L}^{L}-\varepsilon_{H}^{L} \frac{\varepsilon_{L}^{H}}{\varepsilon_{H}^{H}}\right)+\left(1+\varepsilon_{L}^{L}-\varepsilon_{H}^{L} \frac{\varepsilon_{L}^{H}}{\varepsilon_{H}^{H}}\right) \gamma \frac{M^{*}}{L^{*}}+\gamma \frac{w_{M}}{c L^{*}}-1}\right) \hat{b}_{L}
\end{aligned}
$$

where $\hat{b}_{L}=\frac{b_{L}-t_{L} e}{1-t_{L}}$. Therefore we have (see Appendix B)

$$
w_{L}^{*}\left(c, w_{H}, \gamma, t_{L}, e, b_{L}, s\right)=\left(\frac{\bar{\eta}_{L}^{f}}{\bar{\eta}_{L}^{f}-1}\right) \hat{b}_{L}=\frac{\left.\beta L^{*}+(1+\beta) \gamma M^{*}\right)+\gamma \frac{w_{M}}{c}}{\left.(\beta-1) L^{*}+(1+\beta) \gamma M^{*}\right)+\gamma \frac{w_{M}}{c}} \hat{b}_{L}
$$


so that the total wage elasticity also allowing for the relationship between high-skilled and low-skilled wages is $\bar{\eta}_{L}^{f}=\beta\left(1+\gamma \frac{M^{*}}{L^{*}}\right)+\gamma \frac{M^{*}}{L^{*}}+\gamma \frac{w_{M}}{c L^{*}}>1$, where $\beta=\frac{1}{1-\rho(1-a)}>1$ and $M^{*}=\gamma\left(\frac{\gamma w_{L}(1+s)-w_{M}}{c}\right)$. It is important to emphasize that the optimal low-skilled wage (21) even in the case of the monopoly labour union is an implicit form in the presence of outsourcing, because the mark-up $A^{f}=\frac{\beta L^{*}+(1+\beta) \gamma M^{*}+\gamma \frac{w_{M}}{c}}{(\beta-1) L^{*}+(1+\beta) \gamma M^{*}+\gamma \frac{w_{M}}{c}}$ depends on the low-skilled wage rate in a nonlinear way so that it cannot be solved explicitly for the optimal domestic low-skilled wage.

\section{IV.2. Comparative Statics of Wage Formation}

In order to characterize the effect of outsourcing cost on the low-skilled wage formation we therefore apply the implicit differentiation. Differentiating the wage formation (21) with respect to the low-skilled wage and the outsourcing cost gives

$$
\begin{aligned}
& \left(1-\frac{\left[\left(\bar{\eta}_{L}^{f}-1\right) \frac{\partial \bar{\eta}_{L}^{f}}{\partial w_{L}}-\bar{\eta}_{L}^{f} \frac{\partial \bar{\eta}_{L}^{f}}{\partial w_{L}}\right]}{\left(\bar{\eta}_{L}^{f}-1\right)^{2}} \hat{b}_{L}\right) d w_{L}^{*}=\frac{\left[\left(\bar{\eta}_{L}^{f}-1\right) \frac{\partial \bar{\eta}_{L}^{f}}{\partial c}-\bar{\eta}_{L}^{f} \frac{\partial \bar{\eta}_{L}^{f}}{\partial c}\right]}{\left(\bar{\eta}_{L}^{f}-1\right)^{2}} \hat{b}_{L} d c \\
& \text { which can be expressed as } \frac{d w_{L}^{*}}{d c}=-\frac{\frac{\partial \bar{\eta}_{L}^{f}}{\partial c}}{\left(\bar{\eta}_{L}^{f}-1\right)^{2}} \hat{b}_{L} /\left(1+\frac{\frac{\partial \bar{\eta}_{L}^{f}}{\partial w_{L}}}{\left(\bar{\eta}_{L}^{f}-1\right)^{2}} \hat{b}_{L}\right)<0 \text {. Using equation }
\end{aligned}
$$


(21) $\hat{b}_{L}=\frac{w_{L}\left(\bar{\eta}_{L}^{f}-1\right)}{\bar{\eta}_{L}^{f}}$, and calculating $\frac{\partial \bar{\eta}_{L}^{f}}{\partial c}=-\frac{\gamma}{c L^{*}}\left((1+\beta) M^{*}+\frac{w_{M}}{c}\right)\left(1+\gamma \frac{M^{*}}{L^{*}}\right)<0$ (see equation (10)), and

$$
\begin{aligned}
& \frac{\partial \bar{\eta}_{L}^{f}}{\partial w_{L}}=\frac{(1+\beta) \gamma M^{*}}{w_{L} L^{*}}\left[\frac{M_{w_{L}}^{*} w_{L}}{M^{*}}-\frac{L_{w_{L}}^{*} w_{L}}{L^{*}}\right]+\frac{\gamma w_{M}}{c w_{L} L^{*}}\left(-\frac{L_{w_{L}}^{*} w_{L}}{L^{*}}\right)= \\
& \frac{(1+\beta) \gamma M^{*}}{w_{L} L^{*}}\left[1+\frac{w_{M}}{c M^{*}}+\eta_{L}^{f}\right]+\frac{\gamma w_{M}}{c w_{L} L^{*}} \eta_{L}^{f}>0
\end{aligned}
$$

the relationship between the low-skilled wage formation and outsourcing cost can be written as follows

$$
\frac{d w_{L}^{*}}{d c}=-\frac{\frac{\partial \bar{\eta}_{L}^{f}}{\partial c} \frac{w_{L}}{\bar{\eta}_{L}^{f}}}{\bar{\eta}_{L}^{f}-1+\frac{\partial \bar{\eta}_{L}^{f}}{\partial w_{L}} \frac{w_{L}}{\bar{\eta}_{L}^{f}}}>0
$$

so that higher (lower) outsourcing cost will increase (decrease) the wage of low-skilled domestic workers.

Differentiating the implicit wage formation (21) with respect to the productivity of the outsourced low-skilled labour input relative to the domestic low-skilled labour input and low-skilled wage formation gives

$$
\left(1-\frac{\left[\left(\bar{\eta}_{L}^{f}-1\right) \frac{\partial \bar{\eta}_{L}^{f}}{\partial w_{L}}-\bar{\eta}_{L}^{f} \frac{\partial \bar{\eta}_{L}^{f}}{\partial w_{L}}\right]}{\left(\bar{\eta}_{L}^{f}-1\right)^{2}} \hat{b}_{L}\right) d w_{L}^{*}=\frac{\left[\left(\bar{\eta}_{L}^{f}-1\right) \frac{\partial \bar{\eta}_{L}^{f}}{\partial \gamma}-\bar{\eta}_{L}^{f} \frac{\partial \bar{\eta}_{L}^{f}}{\partial \gamma}\right]}{\left(\bar{\eta}_{L}^{f}-1\right)^{2}} \hat{b}_{L} d \gamma
$$

$$
\begin{aligned}
& \text { which can be by } \\
& \frac{\partial \bar{\eta}_{L}^{f}}{\partial \gamma}=(1+\beta) \gamma\left[\frac{L^{*} M_{\gamma}^{*}-M^{*} L_{\gamma}^{*}}{L^{* 2}}\right]+\frac{w_{M}}{c L^{*}}-\frac{\gamma w_{M}}{c} \frac{L_{\gamma}^{*}}{L^{* 2}}=(1+\beta) \frac{M^{*}}{L^{*}} \frac{M_{\gamma}^{*} \gamma}{M^{*}}+ \\
& \left(1+\frac{M_{\gamma}^{*} \gamma}{M^{*}}\right)\left(\gamma \frac{M^{*}}{L^{*}}+\frac{w_{M}}{c L^{*}}\left(1+\gamma \frac{M^{*}}{L^{*}}\right)>0\right.
\end{aligned}
$$


as follows

$$
\frac{d w_{L}^{*}}{d \gamma}=-\frac{\frac{\partial \bar{\eta}_{L}^{f}}{\partial \gamma} \frac{w_{L}}{\bar{\eta}_{L}^{f}}}{\bar{\eta}_{L}^{f}-1+\frac{\partial \bar{\eta}_{L}^{f}}{\partial w_{L}} \frac{w_{L}}{\bar{\eta}_{L}^{f}}}<0
$$

Differentiating the implicit wage formation (21) with respect to the factor price of outsourcing and low-skilled wage formation gives

$$
\left(1-\frac{\left[\left(\bar{\eta}_{L}^{f}-1\right) \frac{\partial \bar{\eta}_{L}^{f}}{\partial w_{L}}-\bar{\eta}_{L}^{f} \frac{\partial \bar{\eta}_{L}^{f}}{\partial w_{L}}\right]}{\left(\bar{\eta}_{L}^{f}-1\right)^{2}} \hat{b}_{L}\right) d w_{L}^{*}=\frac{\left[\left(\bar{\eta}_{L}^{f}-1\right) \frac{\partial \bar{\eta}_{L}^{f}}{\partial w_{M}}-\bar{\eta}_{L}^{f} \frac{\partial \bar{\eta}_{L}^{f}}{\partial w_{M}}\right]}{\left(\bar{\eta}_{L}^{f}-1\right)^{2}} \hat{b}_{L} d w_{M}
$$

which can be expressed as $\frac{d w_{L}^{*}}{d w_{M}}=-\frac{\frac{\partial \bar{\eta}_{L}^{f}}{\partial w_{M}}}{\left(\bar{\eta}_{L}^{f}-1\right)^{2}} \hat{b}_{L} /\left(1+\frac{\frac{\partial \bar{\eta}_{L}^{f}}{\partial w_{L}}}{\left(\bar{\eta}_{L}^{f}-1\right)^{2}} \hat{b}_{L}\right)<0$ so that

$$
\frac{d w_{L}^{*}}{d w_{M}}=-\frac{\frac{\partial \bar{\eta}_{L}^{f}}{\partial w_{H}} \frac{w_{L}}{\bar{\eta}_{L}^{f}}}{\bar{\eta}_{L}^{f}-1+\frac{\partial \bar{\eta}_{L}^{f}}{\partial w_{L}} \frac{w_{L}}{\bar{\eta}_{L}^{f}}}>0
$$

where like in equation (11) we have

$$
\begin{aligned}
& \frac{\partial \bar{\eta}_{L}^{f}}{\partial w_{M}}=\frac{(1+\beta) \gamma M^{*}}{w_{M} L^{*}}\left(\frac{M_{w_{M}}^{*} w_{M}}{M^{*}}-\frac{L_{w_{M}}^{*} w_{M}}{L^{*}}\right)+\frac{\gamma}{c L^{*}}\left(1-\frac{L_{w_{M}}^{*} w_{M}}{L^{*}}\right) \\
& =-\frac{\gamma}{c L^{*}}\left[\beta+\gamma \frac{M^{*}}{L^{*}}\left((1+\beta) \gamma+\frac{w_{M}}{c M^{*}}\right)\right]<0 .
\end{aligned}
$$


Therefore, lower factor price of outsourcing will have a wage moderating effect on the domestic low-skilled wage due to the higher wage elasticity of the low-skilled labour demand.

Moreover, and importantly, equations (23), (25) and (27) jointly with equation (15) imply $\frac{d w_{H}}{d c}<0$ and $\frac{d w_{H}}{d \gamma}>0$ and $\frac{d w_{H}}{d w_{M}}<0$ so that both the lower cost of outsourcing, the higher productivity of the outsourced low-skilled labour input and the lower factor price of outsourcing will have positive effects on the domestic high-skilled wage.

In terms of comparative statics of the low-skilled the wage tax, the tax exemption and the outside option for unemployment benefit we have the following results (see Appendix B)

$$
\begin{aligned}
& \frac{d w_{L}^{*}}{d t_{L}}=\left(\frac{\bar{\eta}_{L}^{f}}{\bar{\eta}_{L}^{f}-1+\frac{\partial \bar{\eta}_{L}^{f}}{\partial w_{L}} \frac{w}{L}_{\bar{\eta}}^{f}}\right) \frac{b_{L}-e}{\left(1-t_{L}\right)^{2}}>0 \text { as } b_{L}-e>0 \\
& \frac{d w_{L}^{*}}{d e}=-\left(\frac{\bar{\eta}_{L}^{f}}{\bar{\eta}_{L}^{f}-1+\frac{\partial \bar{\eta}_{L}^{f}}{\partial w_{L}} \frac{w_{L}}{\bar{\eta}_{L}^{f}}}\right) \frac{t_{L}}{\left(1-t_{L}\right)}<0 \\
& \left.\frac{d w_{L}^{*}}{d b_{L}}=\left(\frac{\bar{\eta}_{L}^{f}}{\bar{\eta}_{L}^{f}-1+\frac{\partial \bar{\eta}_{L}^{f}}{\partial w_{L}} \bar{w}_{L}}\right) \frac{1}{\bar{\eta}_{L}^{f}}\right)>0
\end{aligned}
$$

According to (28a-28c) the effects of wage tax, tax exemption and outside option on low-skilled wage formation are qualitatively the same with and without outsourcing because $\left.\quad \frac{d w_{L}^{*}}{d t_{L}}\right|_{M=0}=\frac{\beta}{(\beta-1)} \frac{b_{L}-e}{\left(1-t_{L}\right)^{2}}>0,\left.\quad \frac{d w_{L}^{*}}{d e}\right|_{M=0}=-\frac{\beta}{(\beta-1)} \frac{t_{L}}{\left(1-t_{L}\right)}<0 \quad$ and $\left.\frac{d w_{L}^{*}}{d b_{L}}\right|_{M=0}=\frac{\beta}{(\beta-1)} \frac{1}{\left(1-t_{L}\right)}>0$. Of course, in the absence of outsourcing the mark-up 
between outside option and wage formation $\left.A\right|_{M=0}=\frac{\beta}{\beta-1}=\frac{1}{\rho(1-a)}>1$ is higher than in the presence of outsourcing. Moreover, the equations (28a-c) imply jointly with equation (15) that $\frac{d w_{H}}{d t_{L}}<0, \frac{d w_{H}}{d e}>0$ and $\frac{d w_{H}}{d b_{L}}<0$ so that the higher wage tax and the higher outside option of low-skilled workers will decrease the wage for the high-skilled labour, while the higher tax exemption of low-skilled workers will increase the wage for the high-skilled labour.

Finally, differentiating the implicit wage formation (21) with respect to the wage of low-skilled workers and the payroll tax gives

$$
\left(1-\frac{\left[\left(\bar{\eta}_{L}^{f}-1\right) \frac{\partial \bar{\eta}_{L}^{f}}{\partial w_{L}}-\bar{\eta}_{L}^{f} \frac{\partial \bar{\eta}_{L}^{f}}{\partial w_{L}}\right]}{\left(\bar{\eta}_{L}^{f}-1\right)^{2}} \hat{b}_{L}\right) d w_{L}^{*}=\frac{\left[\left(\bar{\eta}_{L}^{f}-1\right) \frac{\partial \bar{\eta}_{L}^{f}}{\partial s}-\bar{\eta}_{L}^{f} \frac{\partial \bar{\eta}_{L}^{f}}{\partial s}\right]}{\left(\bar{\eta}_{L}^{f}-1\right)^{2}} \hat{b}_{L} d s
$$

which can be expressed as follows

$$
\frac{d w_{L}^{*}}{d s}=-\frac{\frac{\partial \bar{\eta}_{L}^{f}}{\partial s} \frac{w_{L}^{*}}{\bar{\eta}_{L}^{f}}}{\left[\bar{\eta}_{L}^{f}-1+\frac{\partial \bar{\eta}_{L}^{f}}{\partial w_{L}} \frac{w_{L}^{*}}{\bar{\eta}_{L}^{f}}\right]}<0
$$

because the higher payroll tax will increase the wage elasticity of the low-skilled labour, i.e. for the reason that we have

$$
\frac{\partial \bar{\eta}_{L}^{f}}{\partial s}=(1+\beta) \gamma\left[\frac{L^{*} M_{s}^{*}-M^{*} L_{s}^{*}}{L^{* 2}}\right]+\frac{\gamma w_{M}}{c}\left(-\frac{L_{s}^{*}}{L^{* 2}}\right)=\frac{(1+\beta) \gamma M^{*}}{(1+s) L^{*}}\left(1+\frac{w_{M}}{c M^{*}}+\eta_{s}^{f}\right)+\frac{\gamma w_{M}}{(1+s) L^{*} c} \eta_{s}^{f}>0 .
$$


Therefore, the payroll tax will have a wage moderating effect concerning the lowskilled workers' wage, because the payroll tax will have a positive effect on the wage elasticity. But in the absence of outsourcing it will have no effect on wage formation , i.e. $\left.\frac{\partial \bar{\eta}_{L}^{f}}{\partial s}\right|_{M=0}=0$ because $M=0$.

The total effect of the payroll tax on the high-skilled workers' wage is the following (see Appendix C)

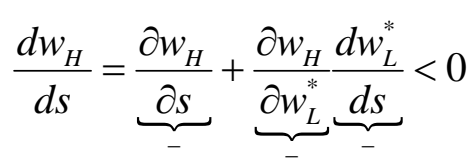

where there is the negative direct effect and the positive indirect effect of the payroll tax, and the total effect is negative. In the absence of outsourcing this is also negative, because $\left.\frac{d w_{L}^{*}}{d s}\right|_{M=0}=0$.

We can now summarize our findings in terms of the low-skilled wage formation in the presence of outsourcing as follows.

Proposition 3 In the presence of flexible outsourcing

(a) the lower cost of outsourcing, the lower factor price of outsourcing and the higher productivity of outsourced production will decrease the wage for the low-skilled labour and increase the wage for the high-skilled labour, thereby inducing higher wage dispersion, and

(b) the higher low-skilled wage tax will increase the wage for the low-skilled labour and decrease the wage for high-skilled labour and the higher lowskilled wage tax exemption will decrease the wage for the low-skilled labour and will increase the wage for the high-skilled labour, and these qualitative results are also similar but higher in the absence of outsourcing, whereas 
(c) the higher payroll tax for the firms will decrease the wage for the lowskilled and for the high-skilled labour. In the absence of outsourcing, the higher payroll tax for the firms will decrease the wage for the high-skilled labour, but has no effect on the wage of low-skilled labour.

According to the first part of this proposition higher outsourcing due to lower outsourcing cost, higher productivity of outsourcing input and lower factor price of outsourcing is perfectly in line with the fact that the outsourced input is a substitute for the low-skilled domestic labour and a complement for the high-skilled domestic labour. According to the second part of this proposition the qualitative effects of wage tax and tax exemption for the low-skilled workers are not changed by flexible outsourcing. The third part of proposition reveals that in the absence of outsourcing the higher payroll tax will have no effect on the wage of the low-skilled labour set by the monopoly union, but in the presence of flexible outsourcing the monopoly union will cut the wage it sets because the own wage elasticity of the low-skilled labour will increase. Finally, the higher payroll tax will have a negative effect the wage for the high-skilled in the presence of outsourcing, and also in the absence of outsourcing.

\section{The Impacts of Low-Skilled Wage Tax Progression}

\section{V.1. Employment Effects}

Next we analyze the effect of wage tax progression on wage formation by the low-skilled workers and labour demand. We assume that the tax reform will keep the relative tax burden per low-skilled worker constant, which means

$$
t_{L}-\frac{t_{L} e}{w_{L}}=R
$$

The government can raise the degree of wage tax progression by increasing $t_{L}$ and $e$ and allowing change in $w_{L}$ under the condition $d R=0$. Formally we have 


$$
\left.\frac{d e}{d t_{L}}\right|_{d R=0,}=\frac{\left(w_{L}^{*}-e+\frac{t_{L} e}{w_{L}^{*}} \frac{\partial w_{L}^{*}}{\partial t_{L}}\right)}{\left(t_{L}-\frac{t_{L} e}{w_{L}^{*}} \frac{\partial w_{L}^{*}}{\partial e}\right)}>0
$$

Concerning the low-skilled wage effect of this reform we have $d w_{L}^{*}=\frac{\partial w_{L}^{*}}{\partial t_{L}} d t_{L}+\frac{\partial w_{L}^{*}}{\partial e} d e$ and dividing by $d t_{L}$ and substituting the RHS of (34) for $d e / d t_{L}$ gives (see Appendix D)

$$
\left.\frac{d w_{L}^{*}}{d t_{L}}\right|_{d R=0}=\frac{\left[\frac{\partial w_{L}^{*}}{\partial t_{L}}+\frac{\left(w_{L}^{*}-e\right)}{t_{L}} \frac{\partial w_{L}^{*}}{\partial e}\right]}{\left[1-\frac{e}{w_{L}^{*}} \frac{\partial w_{L}^{*}}{\partial e}\right]}<0
$$

so that a higher degree of wage tax progression, keeping the relative tax burden per low-skilled worker constant, will decrease the low skilled wage rate. In the absence of outsourcing the qualitative effect is similar, i.e. $\left.\frac{d w_{L}^{*}}{d t_{L}}\right|_{d R=0, d M=0}<0$ (see Appendix D).

Finally, we characterize the low-skilled employment effect by raising tax progression keeping the relative tax burden per low-skilled worker constant to increase $t_{L}$ and $e$ according to (34), so that we have the following employment effect $d L^{*}=\left[L_{w_{L}^{*}}^{*}+L_{w_{H}}^{*} \frac{\partial w_{H}}{\partial w_{L}^{*}}\right]\left[\frac{\partial w_{L}^{*}}{\partial t_{L}} d t_{L}+\frac{\partial w_{L}^{*}}{\partial e} d e\right]$. Dividing this by $d t_{L}$ and substituting the RHS of (34) for $d e / d t_{L}$ gives

$$
\left.\frac{d L^{*}}{d t_{L}}\right|_{d R=0}=\left.\left(L_{w_{L}^{*}}^{*}+L_{w_{H}}^{*} \frac{\partial w_{H}}{\partial w_{L}^{*}}\right) \frac{d w_{L}^{*}}{d t_{L}}\right|_{d R=0 .}=-\frac{L^{*}}{w_{L}^{*}}\left(\beta\left(1+\gamma \frac{M^{*}}{L^{*}}\right)+\gamma \frac{\gamma w_{L}(1+s)}{c L^{*}}\right) \underbrace{\left.\frac{d w_{L}^{*}}{d t_{L}}\right|_{d R=0}}_{-}>0
$$


so that higher degree of wage tax progression keeping the relative tax burden per lowskilled worker constant, will increase the low skilled labour demand. These results (34) and (35) also happen in the case of domestic dual labour markets in the presence of strategic outsourcing (see Koskela and Poutvaara (2008)) and in the case of homogenous domestic labour markets (see Koskela and Schöb (2008)). The qualitative effect is similar in the absence of outsourcing. ${ }^{9}$

The total effect concerning direct and indirect effects of changes in low skilled wage on the high-skilled labour demand is zero, i.e. $d H^{*}=H_{w_{L}^{*}}^{*} d w_{L}^{*}+H_{w_{H}}^{*} \frac{\partial w_{H}}{\partial w_{L}^{*}} d w_{L}^{*}$ can be expressed using equation (12) as

$$
\frac{d H^{*}}{d w_{L}^{*}}=H_{w_{L}^{*}}^{*}+H_{w_{H}}^{*} \frac{\partial w_{H}}{\partial w_{L}^{*}}=\frac{H^{*}}{w_{L}^{*}}\left[\frac{H_{w_{L}^{*}}^{*} w_{L}^{*}}{H^{*}}+\frac{H_{w_{H}}^{*} w_{H}}{H^{*}} \frac{\partial w_{H}}{\partial w_{L}^{*}} \frac{w_{L}^{*}}{w_{H}}\right]=\frac{H^{*}}{w_{L}^{*}}\left[-\varepsilon_{L}^{H}-\varepsilon_{H}^{H} \frac{\partial w_{H}}{\partial w_{L}^{*}} \frac{w_{L}^{*}}{w_{H}}\right]=0
$$

We can now summarize our findings in terms of the low-skilled wage formation and labour demand in the presence of flexible outsourcing as follows.

Proposition 4 In the presence of flexible outsourcing

(a) a higher degree of tax progression by raising the wage tax and the tax exemption for the low-skilled workers to keep the relative burden per worker constant will decrease the wage rate and increase labour demand of low-skilled workers,

(b) while it will have no effect on the labour demand of high-skilled workers and

(c) qualitatively similar effects arise in the absence of outsourcing.

This has been analyzed in the absence of outsourcing e.g. in Koskela and Vilmunen (1996) and in Koskela and Schöb (2002). 
From the perspective of the labour union, an increase in tax progression changes the tradeoff between net wage rate and employment. An increasing progression encourages the labour union to moderate its wage demand, as the opportunity cost of a given new wage increases in terms of additional unemployment increases.

\section{V.2. Welfare Effects}

Now we analyze the welfare effects of low-skilled wage tax progression on the low-skilled trade union objective, the high-skilled Cobb-Douglas utility and the firm's profits by still assuming that the tax reform will keep the relative tax burden per lowskilled worker constant.

The total effect of changes in tax parameters $t_{L}$ and $e$ on the objective function of low-skilled workers $V^{*}=\left(\left(1-t_{L}\right) w_{L}^{*}+t_{L} e-b_{L}\right) L^{*}+b_{L} N=\left(\hat{w}_{L}-b_{L}\right) L^{*}+b_{L} N$ is $d V^{*}=V_{t_{L}}^{*} d t_{L}+V_{e}^{*} d e+V_{w_{L}^{*}}^{*} d w_{L}^{*}$, where $V_{w_{L}^{*}}^{*}=0$ according to the envelope theorem. To keep the relative tax burden per low-skilled worker $t_{L}-\frac{t_{L} e}{w_{L}}=R$ constant means that $\left.d e\right|_{d R=0}=\frac{\left(w_{L}^{*}-e\right)}{t_{L}} d t_{L}+\frac{e}{w_{L}^{*}} d w_{L}^{*}$ and substituting the RHS of this for $d e$ in $d V^{*}=V_{t_{L}}^{*} d t_{L}+V_{e}^{*} d e+V_{w_{L}^{*}}^{*} d w_{L}^{*}$ gives

$$
\left.\frac{d V^{*}}{d t_{L}}\right|_{d R=0}=\underbrace{V_{t_{L}}^{*}+\frac{\left(w_{L}^{*}-e\right)}{t_{L}} V_{e}^{*}}_{=0}+\frac{e}{w_{L}^{*}} V_{e}^{*} \underbrace{\left.\frac{d w_{L}^{*}}{d t_{L}}\right|_{d R=0}<0}_{-}
$$

where $V_{t_{L}}^{*}=-\left(w_{L}^{*}-e\right) L^{*}$ and $V_{e}^{*}=t_{L} L^{*}$ so that $V_{t_{L}}^{*}+\frac{\left(w_{L}^{*}-e\right)}{t_{L}} V_{e}^{*}=0$. Higher low-skilled wage tax progression will decrease the welfare of low-skilled workers by decreasing the wage rate. This also happens in the absence of outsourcing. 
The total effect of changes in tax parameters $t_{L}$ and $e$ on the objective function of high-skilled workers $\quad U^{*}=C^{* \mu} H^{{ }^{1}-\mu}=\left(\left(1-t_{H}\right) w_{H}+t_{H} e_{H}\right)^{\mu} H^{*} \quad$ is $d U^{*}=U_{t_{L}}^{*} d t_{L}+U_{e}^{*} d e+U_{w_{H}}^{*} \frac{\partial w_{H}}{\partial w_{L}^{*}} d w_{L}^{*}$, where $U_{t_{L}}^{*}=U_{e}^{*}=0$ so that we have

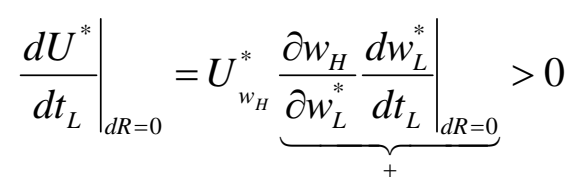

where

$$
U_{w_{H}}^{*}=\mu\left(1-t_{H}\right)\left(\left(1-t_{H}\right) w_{H}+t_{H} e_{H}\right)^{\mu-1} H^{*}+\left(\left(1-t_{H}\right) w_{H}+t_{H} e_{H}\right)^{\mu}\left[H_{w_{L}^{*}}^{*}+H_{w_{H}}^{*} \frac{\partial w_{H}}{\partial w_{L}^{*}}\right]>0
$$

because $\left[H_{w_{L}^{*}}^{*}+H_{w_{H}}^{*} \frac{\partial w_{H}}{\partial w_{L}^{*}}\right]=0$ according to (37). Therefore, higher low-skilled wage tax progression will increase the welfare of high-skilled workers as a result of higher high-skilled wage. This also happens in the absence of outsourcing.

Finally, the total effect of changes in tax parameters $t_{L}$ and $e$ on the firm's profit is $d \pi^{*}=\pi_{t_{L}}^{*} d t_{L}+\pi_{e}^{*} d e+\pi_{w_{L}^{*}}^{*} d w_{L}^{*}$ and to keep $t_{L}-\frac{t_{L} e}{w_{L}}=R$ constant means that $\left.d e\right|_{d R=0}=\frac{\left(w_{L}^{*}-e\right)}{t_{L}} d t_{L}+\frac{e}{w_{L}^{*}} d w_{L}^{*} \quad$ and substituting its RHS for de in $d \pi^{*}=\pi_{t_{L}}^{*} d t_{L}+\pi_{e}^{*} d e+\pi_{w_{L}^{*}}^{*}+\pi_{w_{H}}^{*} \frac{\partial w_{H}}{\partial w_{L}^{*}} d w_{L}^{*}$ gives using the envelope theorem

$$
\left.\frac{d \pi^{*}}{d t_{L}}\right|_{d R=0}=\pi_{t_{L}}^{*}+\frac{\left(w_{L}^{*}-e\right)}{t_{L}} \pi_{e}^{*}+(\pi_{w_{L}^{*}}^{*}+\pi_{w_{H}^{*}}^{*} \frac{\partial w_{H}^{*}}{\partial w_{L}^{*}}+\frac{e}{w_{L}^{*}} \pi_{e}^{*} \underbrace{\left.\frac{d w_{L}^{*}}{d t_{L}}\right|_{d R=0}}_{-}
$$

where $\pi=\left[H^{a}(L+\gamma M)^{1-a}\right]-\widetilde{w}_{H} H-\widetilde{w}_{L} L-w_{M} M-\frac{1}{2} c M^{2} \quad$ so that $\pi_{t_{L}}^{*}=\pi_{e}^{*}=0$, $\pi_{L}^{*}=\pi_{H}^{*}=\pi_{M}^{*}=0$ and $M^{*}=\frac{\left(\not w_{L}(1+s)-w_{M}\right)}{c}$. We can rewrite (40) as follows 


$$
\left.\frac{d \pi^{*}}{d t_{L}}\right|_{d R=0}=\left(\pi_{w_{L}^{*}}^{*}+\pi_{w_{H}}^{*} \frac{\partial w_{H}}{\partial w_{L}^{*}}\right) \underbrace{\left.\frac{d w_{L}^{*}}{d t_{L}}\right|_{d R=0}}_{-}>0
$$

where $\pi_{w_{L}^{*}}^{*}=-(1+s)\left(L+\gamma M^{*}\right)<0$ and $\pi_{w_{H}}^{*}=-(1+s) H^{*}<0$ and $\pi_{w_{L}^{*}}^{*}+\pi_{w_{H}}^{*} \frac{\partial w_{H}}{\partial w_{L}^{*}}<0$

(see Appendix E). Therefore, higher low-skilled wage tax progression by decreasing the low-skilled wage will increase the firm's profit and the qualitative result is similar in the absence of outsourcing.

We can now summarize our findings in terms of the welfare effects of lowskilled tax progression in dual labour markets as follows.

\section{Proposition 5 In the presence of flexible outsourcing}

(a) a higher degree of tax progression, resulting from raising the wage tax and the tax exemption for the low-skilled workers to keep the relative burden per worker constant, will decrease the welfare of low-skilled workers, and

(b) it will increase the welfare of high-skilled workers as a result of higher high-skilled wage, and

(c) it will increase the profit of firms, and

(d) the effects of tax progression are qualitatively similar as in (a)-(c) also in the absence of outsourcing.

The welfare effects are driven by the changed labour union incentives, reported in Proposition 4. Increased tax progression reduces the monopoly rent that the labour union is able to extract, thus resulting in a lower welfare for the low-skilled union members. At the same time, reduced low-skilled wage rate obviously increases the profits of firms already in case the firms would not change their employment, and further when employment changes are accounted for. The high-skilled workers gain due to complementariness in production because higher low-skilled wage tax 
progression will reduce low-skilled wage, and therefore increasing the total use of lowskilled labour by the firms.

\section{Conclusions}

Most western European countries are characterized by dual labour markets, in which wages of some workers are set by labour unions, while other wages are determined competitively. In this paper we have studied how the presence of flexible outsourcing affects such an economy when the low-skilled workers are unionized and the high-skilled workers are employed in competitive labour markets.

We have shown that in the presence of flexible outsourcing the own wage elasticity and the cross wage elasticity for the low-skilled labour demand depend negatively on the cost of outsourcing, and the factor price of outsourcing and positively on the payroll tax, and these elasticities are independent of the cost of outsourcing and the payroll tax for the high-skilled labour demand. By assuming that the market equilibrium for the high-skilled wage follows from the equality of labour demand and labour supply and that the high-skilled workers have a Cobb-Douglas utility function, we find that the high-skilled wage depends negatively on the low-skilled wage and the payroll tax, and it is independent of the high-skilled wage tax parameters. The highskilled wage depends indirectly on the low-skilled wage change and the productivity of outsourced production so that higher outsourcing cost will decrease, while higher productivity of low-skilled labour input relative to the domestic labour input will increase the high-skilled wage.

In the presence of flexible outsourcing the lower cost of outsourcing, the lower factor price of outsourcing and the higher productivity of outsourced production will decrease the wage for the low-skilled labour and increase the wage for the high-skilled labour, thereby inducing higher wage dispersion. Moreover, the higher low-skilled wage tax will increase the wage for the low-skilled labour and decrease the wage for high-skilled labour and the higher low-skilled wage tax exemption will decrease the wage for the low-skilled labour and will increase the wage for the high-skilled labour. The higher payroll tax for the firms will decrease the wage for the low-skilled and 
high-skilled labour, while in the absence of outsourcing, the higher payroll tax for the firms will decrease the wage for the high-skilled labour, but has no effect on the wage of low-skilled labour.

In the presence of flexible outsourcing raising the wage tax and the tax exemption for the low-skilled workers to keep the relative burden per worker constant, this higher degree of tax progression will decrease the wage rate and increase labour demand of low-skilled workers, while it will have no effect on the labour demand of high-skilled workers, and this also works in the absence of outsourcing. Concerning the welfare effects of low-skilled wage tax progression on the low-skilled trade union objective, the high-skilled Cobb-Douglas utility and the firm's profits, we have shown that this higher degree of tax progression will decrease the welfare of low-skilled workers and increase the welfare of high-skilled workers as a result of higher high-skilled wage, while it will increase the profit of firms by decreasing the low-skilled wage.

Our framework suggests several avenues for future research. First of all, we restricted the analysis of tax reforms to the effects of increasing tax progression for low-skilled workers, so that their average tax rate stays the same. An alternative reform scenario would be to assume that the government has a given revenue requirement, and wage tax parameters are changed so that it is still satisfied. In that case, wage taxation would react also to employment changes. One could then also study the effects of a reform that would change the wage tax rate and the payroll tax rate. For example, what would be effects of increasing the low-skilled wage tax rate and lowering the payroll tax, if the change is implemented such that the total government revenue from wage taxes and payroll taxes does not change? Moreover, it is important to study what would be the optimal linear labour tax structure in the presence of outsourcing?

Another important research question would be to compare the effects of flexible outsourcing, analyzed in this paper, with strategic outsourcing in Koskela and Poutvaara (2008). Which regime results in a higher level of outsourcing? How the wage rates of the low-skilled and high-skilled workers differ? Which type of outsourcing results in more low-skilled unemployment? What are the effects on the welfare of different skill types and on the profit rates? Due to complexities involved, it appears that such an analysis would call for a computational general equilibrium model, 
allowing calculating the economic equilibrium in the two scenarios. Doing this is left for future research.

Finally, our research calls for additional empirical work. Establishing how common strategic and flexible outsourcing are in various industries, combined with a theoretical analysis that would compare their economic effects, would allow to estimate economic effects that increasing globalization can be expected to have on European Welfare States.

\section{References:}

Amiti, M. and S.-J. Wei (2005): Fear of Service Outsourcing: Is It justified?, Economic Policy 20, 42, 307-347.

Bingley, P. and G. Lanot (2002): The Incidence of Income Tax on Wages and Labour Supply, Journal of Public Economics, 83, 173-194.

Blundell, R.W. and T. MaCurdy (1999): Labour Supply: A Review of Alternative Approaches, in O. Ashenfelter and D. Card (eds): Handbook of Labor Economics, vol. 3A, 1559-1604.

Braun, F.D. and J. Scheffel (2007): Does International Outsourcing Depress Union Wages?, SFB 649 Discussion Paper, 2007-033, Humbold Universität zu Berlin.

Cahuc, P. and A. Zylberberg (2004): Labor Economics, the MIT Pess.

Daveri, F. ansd G. Tabellini (2000): Unemployment, Growth and Taxation in Industrial Countries, Economic Policy, 30, 49-88.

Davidson, C., S.J. Matuz, and D.R. Nelson (2007): Can Compensation Save Free Trade?, Journal of International Economics, 71, 167-186.

Davidson, C., S.J. Matuz, and A. Shevchenko (2008): Globalization and Firm Level Adjustment with Imperfect Labour Markets, Journal of International Economics, 75, 295-309.

Diehl, M. (1999): The Impact of International Outsourcing on the Skill Structure of Employment: Empirical Evidence from German Manufacturing Industries, Kiel Working Paper No. 496, September.

Egger, H. and P. Egger (2006): International Outsourcing and the Productivity of LowSkilled Labor in the EU, Economic Inquiry, 44, 98-108.

Feenstra, R.C. and G.H. Hanson (1999): The Impact of Outsourcing and HighTechnology Capital on Wages: Estimates for the United States, 1979-1990, Quarterly Journal of Economics, 114, 907-940.

Feenstra, R.C. and G.H. Hanson (2001): Global Production Sharing and Rising Inequality: A Survey of Trade and Wages, NBER Working Paper No. 8372, July.

Freeman, R.B. and R. Schettkat (2001): Marketization of Production and the USEurope Employment Gap, Oxford Bulleting of Economics and Statistics, 63, 647670. 
Freeman, R.B. (2008): Labor Market Institutions Around the World, CEP Discussion Paper No 08-844, January, Washington D.C.

Geischecker, I. and H. Görg (2008): Winners and Losers: A Micro-Level Analysis of International Outsourcing and Wages, Canadian Journal of Economics, 41, 243270.

Görg, H. and A. Hanley (2005): Labour Demand Effects of International Outsourcing: Evidence from Plant-Level Data, International Review of Economics and Finance, 14, 365-376.

Hasan, R., D. Mitra and R.V. Ramaswamy (2007): Trade Reforms, Labor Regulations, and Labor-Demand Elasticities: Empirical Evidence from India, the Review of Economics and Statistics, 89(3), 466-481.

Hijzen, A. (2007): International Outsourcing, Technological Change, and Wage Inequality, Review of International Economics, 15, 188-205.

Hijzen, A., H. Görg and R.C. Hine (2005): International Outsourcing and the Skill Structure of Labour Demand in the United Kingdom, the Economic Journal, 115, 860-878.

Immervoll, H., H.J. Kleven, C.T. Kreiner and E. Saez (2007): Welfare Reform in European Countries: A Microsimulation Analysis, the Economic Journal, 117, 144.

Koskela, E. and P. Poutvaara (2008): Outsourcing and Labor Taxation in Dual Labor Markets, CESifo Working Paper No. 2333, June.

Koskela, E. and R. Schöb (2002): Optimal Factor Income Taxation in the Presence of Unemployment, Journal of Public Economic Theory, 4, 387-404.

Koskela, E. and R. Schöb (2008): Outsourcing of Unionized Firms and the Impact of Labour Market Policy Reforms, IZA Discussion Paper No. 3566, June, University of Bonn.

Koskela, E. and R. Stenbacka (2007): Equilibrium Unemployment with Outsourcing and Wage Solidarity under Labour Market Imperfections, CESifo Working Paper No. 1988, revised in May 2008.

Koskela, E. and J. Vilmunen (1996): Tax Progression is Good for Employment in Popular Models of Trade Union Behaviour, Labour Economics, 3, 65-80.

Lambert, P.J. (2001): The Distribution and Redistribution of Income, $3^{\text {rd }}$ edition, Manchester University Press.

Munch, J.R. and J.R. Skaksen (2005): Specialization, Outsourcing and Wages, IZA Discussion Paper No. 1907, December, University of Bonn, forthcoming in: Review of World Economics.

Musgrave, R.A. and T. Thin (1948): Income Tax Progression, 1929-1948, Journal of Political Economy, 56, 498-514.

Pissarides, C.A. (1998): The Impact of Employment Tax Cuts on Unemployment and Wages: the Role of Unemployment Benefits and Tax Structure, European Economic Review, 42, 155-183.

Riley, R. and G. Young (2007): Skill Heterogeneity and Equilibrium Unemployment, Oxford Economic Papers, 59, 702-725.

Rishi, M. and S. Saxena (2004): Is Outsourcing Really as Bad as It is Made Sound?, Working Paper, University of Pittsburg. 
Senses, M.Z. (2006): The Effects of Outsourcing on the Elasticity of Labor Demand, CES Discussion Paper No. 06-07, March, Washington D.C.

Sinn, H.-W. (2007): The Welfare State and the Forces of Globalization, CESifo Working Paper No. 1925.

Slaughter, M.J. (2001): International Trade and Labor-Demand Elasticities, Journal of International Economics, 54, 27-56.

Stefanova, B.M. (2006): The Political Economy of Outsourcing in the European Union and the East-European Enlargement, Business and Politics 8, issue 2.

\section{Appendix A: Optimal Low-Skilled Labour Demand}

Substituting the RHS of (4) for $H$ into (3b) gives

$\rho\left\{\left(\frac{w_{L}}{w_{H}}\right)^{a}\left(\frac{a}{1-a}\right)^{a}(L+\gamma M)^{a}(L+\gamma M)^{1-a}\right\}^{\rho-1}(1-a)\left(\frac{w_{L}}{w_{H}}\right)^{a}\left(\frac{a}{1-a}\right)^{a}(L+\gamma M)^{a}(L+\gamma M)^{-a}$
$=\widetilde{w}_{L}$

so that $\rho\left\{\left(\frac{w_{L}}{w_{H}}\right)^{a}\left(\frac{a}{1-a}\right)^{a}(L+\gamma M)\right\}^{\rho-1}(1-a)\left(\frac{w_{L}}{w_{H}}\right)^{a}\left(\frac{a}{1-a}\right)^{a}=\tilde{w}_{L}$

which is equivalent to

$(L+\gamma M)^{\rho-1}\left(\frac{w_{L}}{w_{H}}\right)^{a \rho}(1-a)\left(\frac{a}{1-a}\right)^{a \rho}=\rho^{-1} \tilde{w}_{L}$.

(A3) and (5) in its turn give (6). QED.

\section{Appendix B: Optimal Wage Setting under Progressive Wage Taxation and Proportional Payroll Taxation}

The first-order condition associated with $\underbrace{\max }_{\left(w_{L}\right)} V=\left(\left(1-t_{L}\right) w_{L}+t_{L} e-b_{L}\right) L$ s.t. $\pi_{L}=0$ and $H^{*}=H^{s}$ can be written as follows

$$
\begin{aligned}
& V_{w_{L}}=\left(1-t_{L}\right) w_{L}\left(1-\left(\eta_{L}^{f}+\eta_{H}^{f} \frac{\partial w_{H}}{\partial w_{L}} \frac{w_{L}}{w_{H}}\right)\right)+\left(b_{L}-t_{L} e\right)\left(\eta_{L}^{f}+\eta_{H}^{f} \frac{\partial w_{H}}{\partial w_{L}} \frac{w_{L}}{w_{H}}\right) \\
& =\left(1-t_{L}\right) w_{L}\left(\left(1-\gamma \frac{M^{*}}{L^{*}}-\gamma \frac{w_{M}}{c L^{*}}-\left(\varepsilon_{L}^{L}+\varepsilon_{H}^{L} \frac{\partial w_{H}}{\partial w_{L}} \frac{w_{L}}{w_{H}}\right)\left(1+\gamma \frac{M^{*}}{L^{*}}\right)\right)+\right. \\
& \left(b_{L}-t_{L} e\right)\left(\gamma \frac{M^{*}}{L^{*}}+\gamma \frac{w_{M}}{c L^{*}}+\left(\varepsilon_{L}^{L}+\varepsilon_{H}^{L} \frac{\partial w_{H}}{\partial w_{L}} \frac{w_{L}}{w_{H}}\right)\left(1+\gamma \frac{M^{*}}{L^{*}}\right)\right)=0
\end{aligned}
$$


where the own wage elasticity of labour demand is $\eta_{L}^{f}=\varepsilon_{L}^{L}\left(1+\gamma \frac{M^{*}}{L^{*}}\right)+\gamma \frac{M^{*}}{L^{*}}+\gamma \frac{w_{M}}{c L^{*}}=\varepsilon_{L}^{L}+\frac{\gamma}{L^{*}}\left(\left(1+\varepsilon_{L}^{L}\right) M^{*}+\frac{w_{M}}{c}\right)$ and the cross wage elasticity is $\eta_{H}^{f}=\varepsilon_{H}^{L}\left(1+\gamma \frac{M^{*}}{L^{*}}\right)$ and the labour demand under payroll tax is $L^{*}=m w_{L}^{-\varepsilon_{L}^{L}} w_{H}^{-\varepsilon_{H}^{L}}(1+s)^{-\varepsilon}-\gamma M^{*}=m w_{L}^{-\varepsilon_{L}^{L}} w_{H}^{-\varepsilon_{H}^{L}}(1+s)^{-\varepsilon}-\gamma\left(\frac{\gamma w_{L}(1+s)-w_{M}}{c}\right)$. In the case of the C-D utility function we have

$w_{H}=\left[\frac{\mu(1-a)}{m a}\right]^{-\frac{1}{\varepsilon_{H}^{H}}} w_{L}^{-\frac{\varepsilon_{L}^{H}}{\varepsilon_{H}^{H}}}(1+s)^{-\frac{\varepsilon}{\varepsilon_{H}^{H}}}$

so that

$\frac{\partial w_{H}}{\partial w_{L}}=-\frac{\varepsilon_{L}^{H}}{\varepsilon_{H}^{H}}\left[\frac{\mu(1-a)}{m a}\right]^{-\frac{1}{\varepsilon_{H}^{H}}} w_{L}^{-\frac{\varepsilon_{L}^{H}}{\varepsilon_{H}^{H}}-1}(1+s)^{-\frac{\varepsilon}{\varepsilon_{H}^{H}}}=-\frac{\varepsilon_{L}^{H}}{\varepsilon_{H}^{H}} \frac{w_{H}}{w_{L}}<0$

Using (B2) and (B3) gives $\frac{\partial w_{H}}{\partial w_{L}} \frac{w_{L}}{w_{H}}=-\frac{\varepsilon_{L}^{H}}{\varepsilon_{H}^{H}}=-\frac{\rho(1-a)}{1-\rho(1-a)}<0$, which implies the equation (21) because

$\varepsilon_{L}^{L}-\varepsilon_{H}^{L} \frac{\varepsilon_{L}^{H}}{\varepsilon_{H}^{H}}=\frac{\varepsilon_{L}^{L} \varepsilon_{H}^{H}-\varepsilon_{H}^{L} \varepsilon_{L}^{H}}{\varepsilon_{H}^{H}}=\frac{(1-\rho a)(1-\rho(1-a))-\rho a \rho(1-a)}{(1-\rho(1-a))(1-\rho)}=\frac{1}{1-\rho(1-a)}=\beta>1$.

Differentiating (21) in terms of low-skilled wage and wage tax rate gives

$\left(1-\frac{\left[\left(\bar{\eta}_{L}^{f}-1\right) \frac{\partial \bar{\eta}_{L}^{f}}{\partial w_{L}}-\bar{\eta}_{L}^{f} \frac{\partial \bar{\eta}_{L}^{f}}{\partial w_{L}}\right]}{\left(\bar{\eta}_{L}^{f}-1\right)^{2}} \hat{b}_{L}\right) d w_{L}^{*}=\frac{\bar{\eta}_{L}^{f}}{\left(\bar{\eta}_{L}^{f}-1\right)} \frac{b_{L}-e}{\left(1-t_{L}\right)^{2}} d t_{L}$

and using $\hat{b}_{L}=\frac{w_{L}\left(\bar{\eta}_{L}^{f}-1\right)}{\bar{\eta}_{L}^{f}}$, (B4) can be expressed as

$\left(1+\frac{\frac{\partial \bar{\eta}_{L}^{f}}{\partial w_{L}} \frac{w_{L}}{\bar{\eta}_{L}^{f}}}{\left(\bar{\eta}_{L}^{f}-1\right)}\right) d w_{L}^{*}=\frac{\bar{\eta}_{L}^{f}}{\left(\bar{\eta}_{L}^{f}-1\right)} \frac{b_{L}-e}{\left(1-t_{L}\right)^{2}} d t_{L}$ 
which gives (28a). Of course, the equations (28b) and (28c) can be derived in the similar way. QED.

\section{Appendix C: The total effect of the payroll tax on the high-skilled workers' wage}

Using equations (15), (16), (30) and (31) the equation (32) can be expressed as

$$
\frac{d w_{H}}{d s}=-\frac{\varepsilon}{\varepsilon_{H}^{H}} \frac{w_{H}}{(1+s)}+\frac{\varepsilon_{L}^{H}}{\varepsilon_{H}^{H}} \frac{\frac{\partial \bar{\eta}_{L}^{f}}{\partial s} \frac{w_{H}}{\bar{\eta}_{L}^{f}}}{\left[\bar{\eta}_{L}^{f}-1+\frac{\partial \bar{\eta}_{L}^{f}}{\partial w_{L}} \frac{w_{L}^{*}}{\bar{\eta}_{L}^{f}}\right]}
$$

so that

$$
\begin{aligned}
& \frac{d w_{H}}{d s}=-\frac{\varepsilon w_{H}}{\varepsilon_{H}^{H}(1+s)}\left[1-\frac{\varepsilon_{L}^{H}\left[\frac{\partial \bar{\eta}_{L}^{f}}{\partial s}\right] \frac{1}{\bar{\eta}_{L}^{f}}(1+s)}{\varepsilon\left[\bar{\eta}_{L}^{f}-1+\frac{\partial \bar{\eta}_{L}^{f}}{\partial w_{L}} \frac{w_{L}^{*}}{\bar{\eta}_{L}^{f}}\right]}\right]= \\
& -\frac{\varepsilon w_{H}}{\varepsilon_{H}^{H}(1+s) \varepsilon\left[\bar{\eta}_{L}^{f}-1+\frac{\partial \bar{\eta}_{L}^{f}}{\partial w_{L}} \frac{w_{L}^{*}}{\bar{\eta}_{L}^{f}}\right]}\left(\varepsilon\left(\bar{\eta}_{L}^{f}-1+\frac{\partial \bar{\eta}_{L}^{f}}{\partial w_{L}} \frac{w_{L}^{*}}{\bar{\eta}_{L}^{f}}\right)-\varepsilon_{L}^{H}(1+s)\left[\frac{\partial \bar{\eta}_{L}^{f}}{\partial s}\right] \frac{1}{\bar{\eta}_{L}^{f}}\right)
\end{aligned}
$$

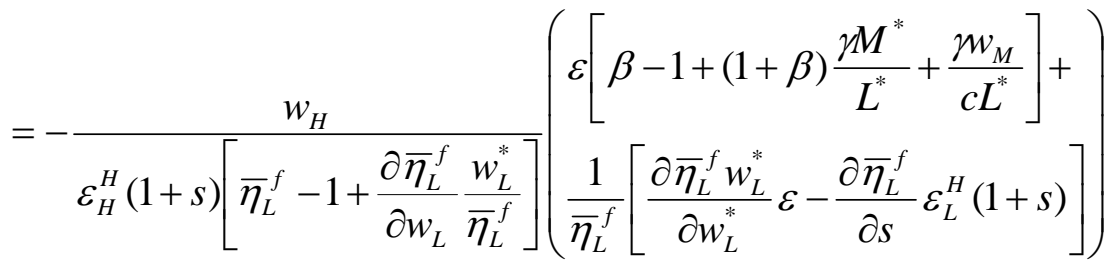

$$
\begin{aligned}
& =-\frac{w_{H}}{\varepsilon_{H}^{H}(1+s)\left[\bar{\eta}_{L}^{f}-1+\frac{\partial \bar{\eta}_{L}^{f}}{\partial w_{L}} \frac{w_{L}^{*}}{\bar{\eta}_{L}^{f}}\right]}\left(\begin{array}{l}
\varepsilon\left[\beta-1+(1+\beta) \frac{\gamma M^{*}}{L^{*}}+\frac{\gamma w_{M}}{c L^{*}}\right]+ \\
\left.\frac{1}{\bar{\eta}_{L}^{f}}\left[\begin{array}{l}
\varepsilon(1+\beta) \gamma \frac{M^{*}}{L^{*}}\left(1+\frac{w_{M}}{c M^{*}}+\eta_{L}^{f}\right)+\varepsilon \gamma \frac{w_{M}}{c L^{*}} \eta_{L}^{f}- \\
\varepsilon_{L}^{H}(1+\beta) \gamma \frac{M^{*}}{L^{*}}\left(1+\frac{w_{M}}{c M^{*}}+\eta_{s}^{f}\right)-\varepsilon_{L}^{H} \gamma \frac{w_{M}}{c L^{*}} \eta_{s}^{f}
\end{array}\right]\right)<0
\end{array}\right)<
\end{aligned}
$$

QED. 


\section{Appendix D: Tax Progression and Low-Skilled Labour Demand}

Substituting the RHS of (34) into $d w_{L}^{*}=\frac{\partial w_{L}^{*}}{\partial t_{L}} d t_{L}+\frac{\partial w_{L}^{*}}{\partial e} d e$ implies

$$
\left.\frac{d w_{L}^{*}}{d t_{L}}\right|_{d R=0}=\frac{\left(\frac{\partial w_{L}^{*}}{\partial t_{L}} t_{L}\left(1-\frac{e}{w_{L}^{*}} \frac{\partial w_{L}^{*}}{\partial e}\right)+\frac{\partial w_{L}^{*}}{\partial e}\left(w_{L}^{*}-e\right)+\frac{\partial w_{L}^{*}}{\partial e} \frac{t_{L} e}{w_{L}^{*}} \frac{\partial w_{L}^{*}}{\partial t_{L}}\right)}{t_{L}\left[1-\frac{e}{w_{L}^{*}} \frac{\partial w_{L}^{*}}{\partial e}\right]}
$$

which gives (35), where the denominator is positive. Concerning the numerator $\frac{\partial w_{L}^{*}}{\partial t_{L}}+\frac{\left(w_{L}^{*}-e\right)}{t_{L}} \frac{\partial w_{L}^{*}}{\partial e}$ in (35) we obtain that it is negative, i.e.

$$
\frac{\partial w_{L}^{*}}{\partial t_{L}}+\frac{\left(w_{L}^{*}-e\right)}{t_{L}} \frac{\partial w_{L}^{*}}{\partial e}=\frac{D}{\left(1-t_{L}\right)^{2}}\left(b_{L}-\hat{w}_{L}\right)<0
$$

where $\quad D=\frac{\bar{\eta}_{L}^{f}}{\bar{\eta}_{L}^{f}-1+\frac{\partial \bar{\eta}_{L}^{f}}{\partial w_{L}} \frac{w_{L}}{\bar{\eta}_{L}^{f}}}>0$ and $b_{L}-\hat{w}_{L}=b_{L}-\left(w_{L}^{*}\left(1-t_{L}\right)+t_{L} e\right)<0$. In the absence of outsourcing we have the same qualitative result $\left.\frac{d w_{L}^{*}}{d t_{L}}\right|_{d R=0, M=0}=\left[\frac{\partial w_{L}^{*}}{\partial t_{L}}+\frac{\left(w_{L}^{*}-e\right)}{t_{L}} \frac{\partial w_{L}^{*}}{\partial e}\right]_{M=0}=\frac{\beta}{(\beta-1)\left(1-t_{L}\right)^{2}}\left(b_{L}-\hat{w}_{L}\right)<0$. QED.

\section{Appendix E: Tax Progression and Welfare Effect of Firms}

Concerning $\left(\pi_{w_{L}^{*}}^{*}+\pi_{w_{H}}^{*} \frac{\partial w_{H}}{\partial w_{L}^{*}}\right)$ in equation (41) we have $\pi_{w_{L}^{*}}^{*}=-(1+s)\left(L^{*}+\gamma M^{*}\right)<0$ and $\pi_{w_{H}}^{*}=-(1+s) H^{*}<0$ so that

$$
\pi_{w_{L}^{*}}^{*}+\pi_{w_{H}}^{*} \frac{\partial w_{H}}{\partial w_{L}^{*}}=-(1+s)\left[L^{*}+\gamma M^{*}+H^{*} \frac{\partial w_{H}}{\partial w_{L}^{*}}\right]=-(1+s)\left[L^{*}+\gamma M^{*}-H^{*} \frac{\varepsilon_{L}^{H}}{\varepsilon_{H}^{H}} \frac{w_{H}}{w_{L}^{*}}\right](
$$


where

$$
L^{*}+\gamma M^{*}=m w_{L}^{*-\varepsilon_{L}^{L}} w_{H}^{-\varepsilon_{H}^{L}}(1+s)^{-\varepsilon}
$$

and

$-H^{*} \frac{\varepsilon_{L}^{H}}{\varepsilon_{H}^{H}} \frac{w_{H}}{w_{L}^{*}}=-\frac{m \rho a}{1-\rho(1-a)} w_{H}^{1-\varepsilon_{H}^{H}} w_{L}^{{ }^{*}-1-\varepsilon_{L}^{H}}(1+s)^{-\varepsilon}$. Using $\varepsilon_{H}^{H}-1=\varepsilon_{H}^{L}$ and $\varepsilon_{L}^{H}+1=\varepsilon_{L}^{L}$

equation (E1) can be expressed as

$$
\pi_{w_{L}^{*}}^{*}+\pi_{w_{H}}^{*} \frac{\partial w_{H}}{\partial w_{L}^{*}}=-\left(L^{*}+\gamma M^{*}\right) \frac{1-\rho}{1-\rho(1-a)}<0 . \text { QED }
$$




\section{CESifo Working Paper Series}

for full list see www.cesifo-group.org/wp

(address: Poschingerstr. 5, 81679 Munich, Germany, office@cesifo.de)

2381 Sebastian Buhai, Miguel Portela, Coen Teulings and Aico van Vuuren, Returns to Tenure or Seniority?, August 2008

2382 Erkki Koskela and Jan König, Flexible Outsourcing, Profit Sharing and Equilibrium Unemployment, August 2008

2383 Torberg Falch and Justina AV Fischer, Does a Generous Welfare State Crowd out Student Achievement? Panel Data Evidence from International Student Tests, September 2008

2384 Pedro Gomes and François Pouget, Corporate Tax Competition and the Decline of Public Investment, September 2008

2385 Marko Koethenbuerger, How Do Local Governments Decide on Public Policy in Fiscal Federalism? Tax vs. Expenditure Optimization, September 2008

2386 Ronald McKinnon and Gunther Schnabl, China's Exchange Rate Impasse and the Weak U.S. Dollar, September 2008

2387 Yan-Leung Cheung, Yin-Wong Cheung and Alan T.K. Wan, A High-Low Model of Daily Stock Price Ranges, September 2008

2388 Louis Eeckhoudt and Harris Schlesinger, Changes in Risk and the Demand for Saving, September 2008

2389 Carsten Hefeker and Blandine Zimmer, Uncertainty and Fiscal Policy in an Asymmetric Monetary Union, September 2008

2390 Jay Pil Choi and Byung-Cheol Kim, Net Neutrality and Investment Incentives, September 2008

2391 Marcel Gérard, Financing Bologna, the Internationally Mobile Students in European Higher Education, September 2008

2392 Annette Alstadsæter and Knut Reidar Wangen, Corporations' Choice of Tax Regime when Transition Costs are Small and Income Shifting Potential is Large, September 2008

2393 António Afonso and Christophe Rault, 3-Step Analysis of Public Finances Sustainability: the Case of the European Union, September 2008

2394 Betsey Stevenson and Justin Wolfers, Economic Growth and Subjective Well-Being: Reassessing the Easterlin Paradox, September 2008 
2395 Bernhard Eckwert and Itzhak Zilcha, Private Investment in Higher Education: Comparing Alternative Funding Schemes, September 2008

2396 Øystein Foros, Hans Jarle Kind and Jan Yngve Sand, Slotting Allowances and Manufacturers' Retail Sales Effort, September 2008

2397 Mohammad Reza Farzanegan, Illegal Trade in the Iranian Economy: Evidence from a Structural Model, September 2008

2398 Olivier Bos, Charity Auctions for the Happy Few, September 2008

2399 Robert S. Chirinko and Debdulal Mallick, The Marginal Product of Capital: A Persistent International Puzzle, September 2008

2400 Ben D'Exelle and Arno Riedl, Elite Capture, Political Voice and Exclusion from Aid: An Experimental Study, September 2008

2401 Torben M. Andersen and Joydeep Bhattacharya, On Myopia as Rationale for Social Security, September 2008

2402 Fabienne Llense, French CEO Compensations: What is the Cost of a Mandatory Upper Limit?, September 2008

2403 Valentina Bosetti, Carlo Carraro, Alessandra Sgobbi and Massimo Tavoni, Delayed Action and Uncertain Targets. How Much Will Climate Policy Cost?, September 2008

2404 Robert G. Chambers, Rolf Färe, Shawna Grosskopf and Michael Vardanyan, Generalized Quadratic Revenue Functions, September 2008

2405 Leonidas Enrique de la Rosa, Overconfidence in a Career-Concerns Setting, September 2008

2406 Marcus Drometer and Johannes Rincke, The Design of Political Institutions: Electoral Competition and the Choice of Ballot Access Restrictions in the United States, September 2008

2407 Markku Lanne and Helmut Lütkepohl, Stock Prices and Economic Fluctuations: A Markov Switching Structural Vector Autoregressive Analysis, September 2008

2408 Thomas L. Brewer, International Energy Technology Transfers for Climate Change Mitigations, September 2008

2409 Alexander Kemnitz, Native Welfare Losses from High Skilled Immigration, September 2008

2410 Xavier Vives, Strategic Supply Function Competition with Private Information, September 2008 
2411 Fabio Padovano and Roberto Ricciuti, The Political Competition-Economic Performance Puzzle: Evidence from the OECD Countries and the Italian Regions, September 2008

2412 Joan Costa-Font and Mireia Jofre-Bonet, Body Image and Food Disorders: Evidence from a Sample of European Women, September 2008

2413 Thorsten Upmann, Labour Unions - To Unite or to Separate?, October 2008

2414 Sascha O. Becker and Ludger Woessmann, Luther and the Girls: Religious Denomination and the Female Education Gap in $19^{\text {th }}$ Century Prussia, October 2008

2415 Florian Englmaier and Stephen Leider, Contractual and Organizational Structure with Reciprocal Agents, October 2008

2416 Vittorio Daniele and Ugo Marani, Organized Crime and Foreign Direct Investment: The Italian Case, October 2008

2417 Valentina Bosetti, Carlo Carraro, Alessandra Sgobbi and Massimo Tavoni, Modelling Economic Impacts of Alternative International Climate Policy Architectures. A Quantitative and Comparative Assessment of Architectures for Agreement, October 2008

2418 Paul De Grauwe, Animal Spirits and Monetary Policy, October 2008

2419 Guglielmo Maria Caporale, Christophe Rault, Robert Sova and Anamaria Sova, On the Bilateral Trade Effects of Free Trade Agreements between the EU-15 and the CEEC-4 Countries, October 2008

2420 Yin-Wong Cheung and Daniel Friedman, Speculative Attacks: A Laboratory Study in Continuous Time, October 2008

2421 Kamila Fialová and Ondřej Schneider, Labour Market Institutions and their Effect on Labour Market Performance in the New EU Member Countries, October 2008

2422 Alexander Ludwig and Michael Reiter, Sharing Demographic Risk - Who is Afraid of the Baby Bust?, October 2008

2423 Doina Maria Radulescu and Michael Stimmelmayr, The Welfare Loss from Differential Taxation of Sectors in Germany, October 2008

2424 Nikolaus Wolf, Was Germany ever United? Evidence from Intra- and International Trade 1885 - 1933, October 2008

2425 Bruno S. Frey, David A. Savage and Benno Torgler, Noblesse Oblige? Determinants of Survival in a Life and Death Situation, October 2008

2426 Giovanni Facchini, Peri Silva and Gerald Willmann, The Customs Union Issue: Why do we Observe so few of them?, October 2008 
2427 Wido Geis, Silke Uebelmesser and Martin Werding, Why go to France or Germany, if you could as well go to the UK or the US? Selective Features of Immigration to four major OECD Countries, October 2008

2428 Geeta Kingdon and Francis Teal, Teacher Unions, Teacher Pay and Student Performance in India: A Pupil Fixed Effects Approach, October 2008

2429 Andreas Haufler and Marco Runkel, Firms' Financial Choices and Thin Capitalization Rules under Corporate Tax Competition, October 2008

2430 Matz Dahlberg, Heléne Lundqvist and Eva Mörk, Intergovernmental Grants and Bureaucratic Power, October 2008

2431 Alfons J. Weichenrieder and Tina Klautke, Taxes and the Efficiency Costs of Capital Distortions, October 2008

2432 Andreas Knabe and Ronnie Schöb, Minimum Wage Incidence: The Case for Germany, October 2008

2433 Kurt R. Brekke and Odd Rune Straume, Pharmaceutical Patents: Incentives for R\&D or Marketing?, October 2008

2434 Scott Alan Carson, Geography, Insolation, and Institutional Change in $19^{\text {th }}$ Century African-American and White Stature in Southern States, October 2008

2435 Emilia Del Bono and Daniela Vuri, Job Mobility and the Gender Wage Gap in Italy, October 2008

2436 Marco Angrisani, Antonio Guarino, Steffen Huck and Nathan Larson, No-Trade in the Laboratory, October 2008

2437 Josse Delfgaauw and Robert Dur, Managerial Talent, Motivation, and Self-Selection into Public Management, October 2008

2438 Christian Bauer and Wolfgang Buchholz, How Changing Prudence and Risk Aversion Affect Optimal Saving, October 2008

2439 Erich Battistin, Clara Graziano and Bruno Parigi, Connections and Performance in Bankers' Turnover: Better Wed over the Mixen than over the Moor, October 2008

2440 Erkki Koskela and Panu Poutvaara, Flexible Outsourcing and the Impacts of Labour Taxation in European Welfare States, October 2008 